\title{
EFEITOS DA SUPLEMENTAÇÃO DE ALTOS NIVEIS DIETÉTICOS DE COBRE E ZINCO NO DESEMPENHO DE LEITÕES
}

\author{
NELSON JUÁN PEREIRA MAMANI \\ Médico Veterinário-Zootecnista
}

Orientador: Prof. Dr. VALDOMIRO SHIGUERU MIYADA

Dissertaçăo apresentada à Escola Superior de Agricultura "Luiz de Queiroz", da Universidade de São Paulo, para obtenção do título de Mestre em Agronomia, Área de Concentraçăo: Ciéncia Animal e Pastagens.

PIRACICABA

Estado de São Paulo - Brasil

Novembro - 1996 
Dados Internacionais de Catalogação na Publicação (CIP) DIVISÃO DE BIBLIOTECA E DOCUMENTAÇĀO - Campus “Luiz de Queiroz"/USP

Pereira Mamani, Nelson Juán Efeitos da suplementação de altos níveis dietéticos de cobre e zinco no desempenho de leitōes / Nelson Juán Pereira Mamani. - - Piracicaba, 1996.

62 p. : il.

Dissertação (mestrado) - - Escola Superior de Agricultura Luiz de Queiroz, 1996. Bibliografia.

1. Leitão - Crescimento 2. Leitão - Nutrição - Efeito 3. Mineral em ração I. Titulo CDD 636.4085 


\section{EFEITOS DA SUPLEMENTAÇÃO DE ALTOS NIVVEIS DIETÉTICOS DE COBRE E ZINCO NO DESEMPENHO DE LEITÕES}

Nelson Juán Pereira Mamani

Aprovada em: $28 / 11 / 96$

COMISSÃO JUGADORA:

Prof. Dr. Valdomiro Shigueru Miyada

Prof. Dr. Irineu Umberto Packer

ESALQ / USP

Prof. Dr. Rodolfo Nascimento Kronka

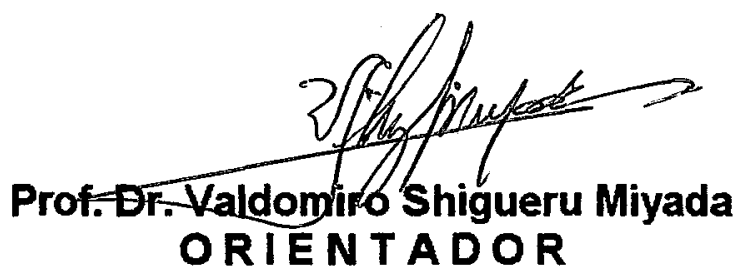


Nos Meus Pais:

Alfredo Pereira Cabrera (in memoria),

fuliana Mamani fanco

Oereco

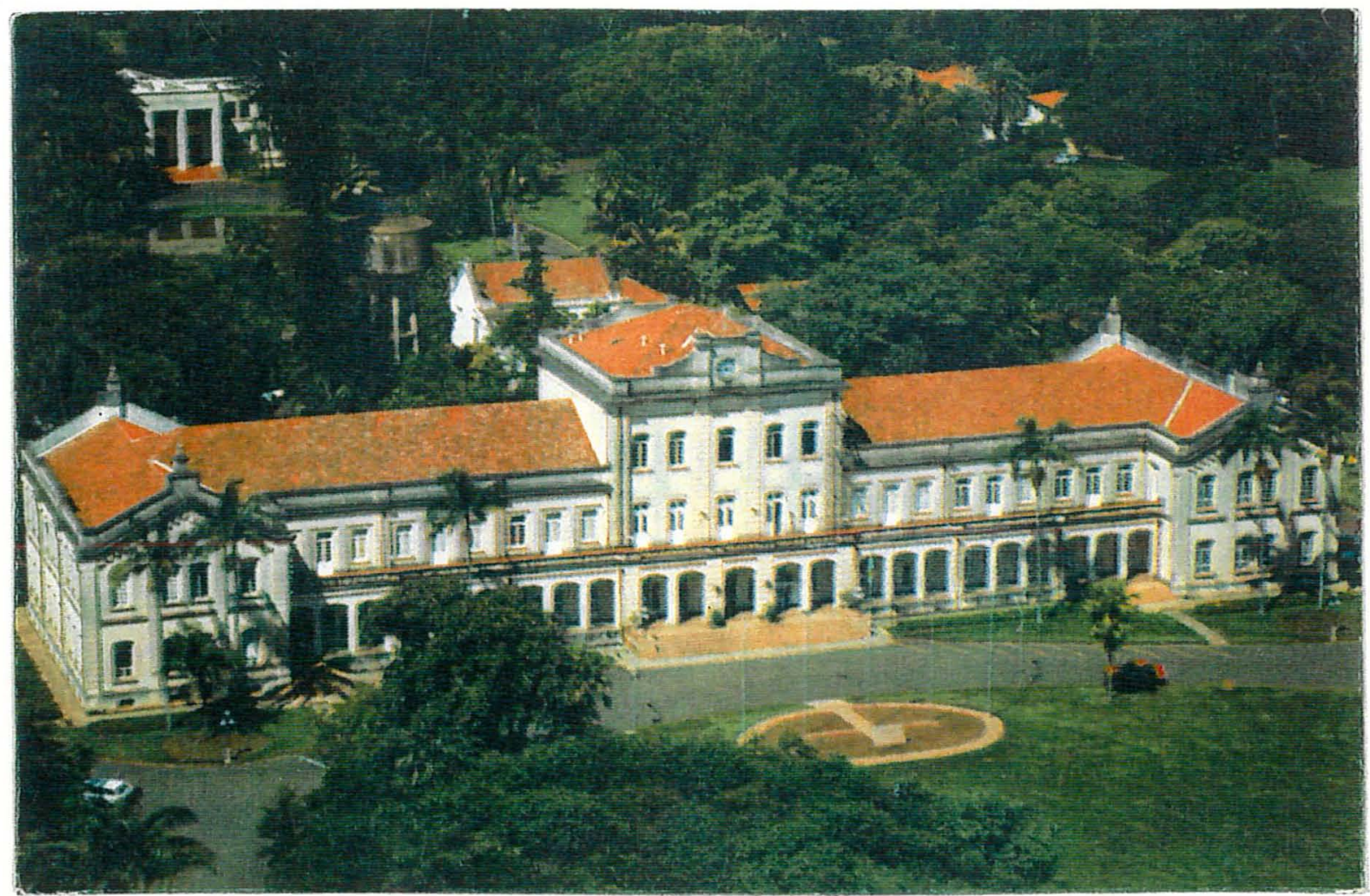

A Raqual Viricachea, minha namorada, e irmãos: Franklin, Edwin, Mario, Allredo, Willert a Nancy Dedico. 


\section{AGRADECIMENTOS}

- Ao Prof. Dr. Valdomiro Shigueru Miyada, pela orientação e valiosas sugestōes e, apesar de seu tempo escasso, não economizou esforços para ajudar a aprimorar este trabalho;

- Agradecimento especial aos responsáveis pelas instituições que financiam o ensino e a pesquisa no Brasil, principalmente à Fundação Coordenação de Aperfeiçoamento de Pessoal de Nivel Superior (CAPES), pela concessão da bolsa de estudo;

- À Escola Superior de Agricultura "Luiz de Queiroz", pela oportunidade de realização deste curso, em especial ao Departamento de Zootecnia, por oferecer condições de estudo e de infraestrutura para a condução do experimento;

- Aos professores Irineu U. Packer, Décio Barbin e Luís Salvarrey pelas sugestőes referentes à análise estatística;

- Aos professores do curso, pelos ensinamentos, dedicaçăo e amizade;

- Às minhas melhores alunas de espanhol da ESALQ/USP, Prof ${ }^{a}$. Dra ${ }^{a}$. Solange Guidolin C. Brazaca e Prof". Dr". Jocelem Mastrodi Salgado pelas valiosas sugestőes, amizade, apoio e correções do português;

- Aos funcionários do Setor de Suinocultura do Departamento de Zootecnia, pelo auxílio nos trabalhos de campo;

- Ao colega Fábio A. Botelho, pela colaboraçăo durante a fase experimental, e ao amigo Alexandre pela correção do portugués;

- Aos amigos de casa, em especial:Welington pela agradável convivência e pela correção do português;

- Aos colegas da pós-graduaçăo, brasileiros e estrangeiros, pela amizade e convivência; 
ÍNDICE

Página

LISTA DE TABELAS ...................................................................................

LISTA DE FIGURAS ……......................................................................

LISTA DE TABELAS DO APÊNDICE ........................................................ viii

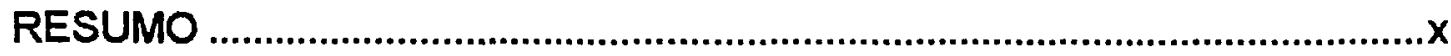

SUMMARY

1. INTRODUÇÃO

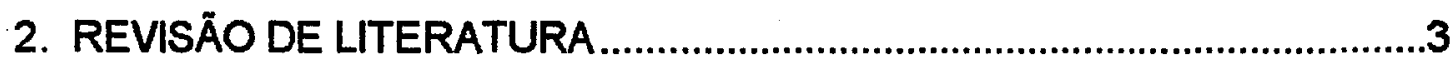

2.1. Metabolismo e funçð̄es metabólicas do cobre .......................................3

2.2. Metabolismo e funçžes metabólicas do zinco........................................5

2.3. Efeitos de altos niveis de cobre suplementar como promotores do crescimento em suínos...............................................7

2.4. Efeitos de altos niveis de zinco suplementar como promotores do crescimento em suínos..................................................

2.5. Interaçర̃es afetando a absorçăo e o metabolismo

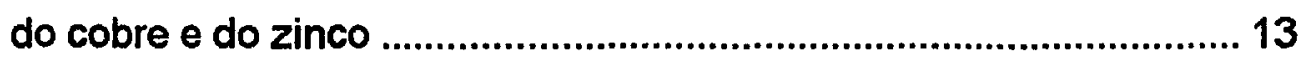

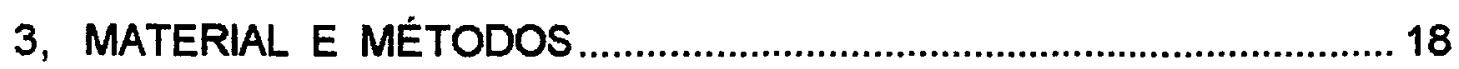

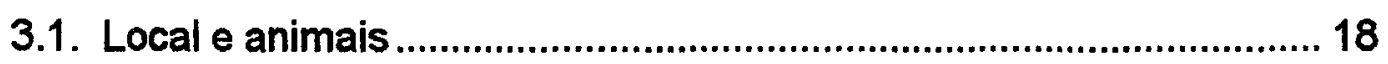

3.2. Ração basal e tratamentos............................................................. 18

3.3. Manejo e colheita de dados................................................................. 21

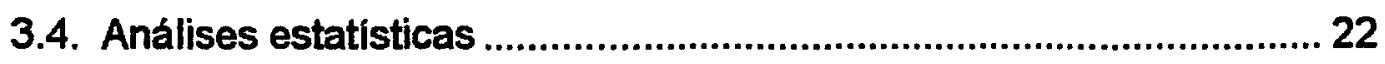

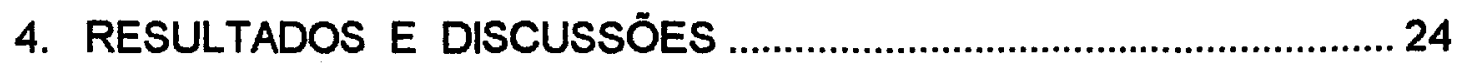

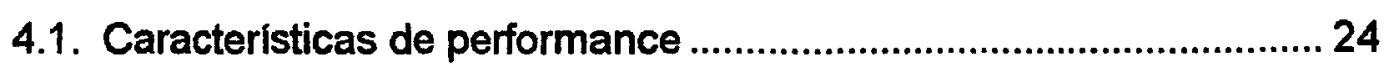

4.2. Componentes sanguíneos e plasmáticos........................................... 32

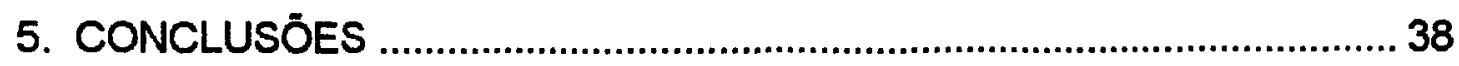

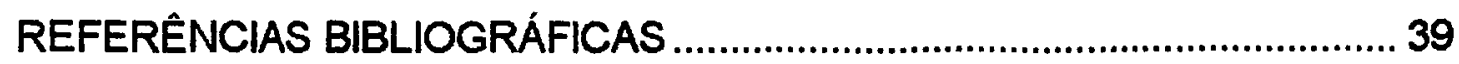

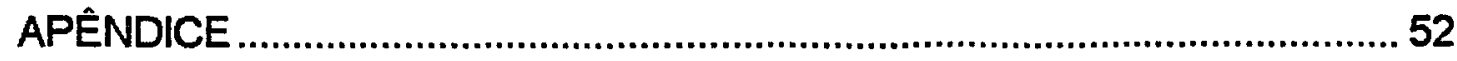




\section{LISTA DE TABELAS}

TABELA N ${ }^{\circ}$

Página

01 Composição percentual da ração basal 19

02 Efeitos da suplementação de cobre e zinco na raçăo sobre ganho diário médio de peso (GDP, g), consumo diário médio de raçăo (CDR, g) e conversão alimentar média (CA) de suínos em recria (semanas 1 e 2 e semanas 1 a 4)

03 Efeitos da suplementação de cobre e zinco na ração sobre os componentes sanguíneos e plasmáticos de suínos em recria 


\section{LISTA DE FIGURAS}

FIGURA No

Página

01 Efeitos da suplementação de cobre e zinco na ração sobre o ganho diário médio de peso (GDP, g), consumo diário médio de raçăo (CDR, g) e conversão alimentar média (CA) de leitões em recria (semanas 1 e 2 e semanas 1 a 4 ) 26

02 Efeitos de combinações de altos níveis suplementares de cobre e zinco na ração sobre ganho diário médio de peso (GDP, g) de leitöes em recria (semanas 1 e 2 e semanas 1 a 4 )

03 Efeitos de combinaçס̃es de altos niveis suplementares de cobre e zinco na ração sobre o consumo diário médio de ração (CDR, g) de leitões em recria (semanas 1 e 2 e semanas 1 a 4).

04 Efeitos de combinações de altos niveis suplementares de cobre e zinco na ração sobre o hematócrito $(\mathrm{Ht}, \%)$ e hemoglobina $(\mathrm{Hb}, \mathrm{g} / \mathrm{dl})$ do sangue dos leitőes em recria. 


\section{LISTA DE TABELAS DO APÊNDICE}

TABELA No

Página

A1 Resultados da performance dos leitóes suplementados com altos niveis de $\mathrm{Cu}$ e $\mathrm{Zn}$ na ração (semanas 1 e 2)

A2 Resultados da performance dos leitóes suplementados com altos niveis de Cu e $\mathrm{Zn}$ na ração (semanas 1 a 4). 54

A3 Análises estatísticas dos dados de ganho diário médio de peso (GDP, g) dos leitões suplementados com altos niveis de Cu e $Z n$ na ração (semanas 1 e 2 e semanas 1 a 4) .55

A4 Análises estatísticas dos dados de consumo diário médio de raçăo (CDR, g) dos leitōes suplementados com altos niveis de Cu e $\mathrm{Zn}$ na ração (semanas 1 e 2 e semanas 1 a 4) .56

A5 Análises estatísticas dos dados de conversăo alimentar média (CA) dos leitões suplementados com altos niveis de Cu e $\mathrm{Zn}$ na ração (semanas 1 a 2 e semanas 1 a 4)

A6 Resultados dos componentes sanguíneos (hematócrito e hemoglobina) e plasmáticos (proteína total, albumina, globulina, relação albumina/globulina e uréia) dos leitőes suplementados com altos niveis de $\mathrm{Cu}$ e $\mathrm{Zn}$ na ração. 
A7 Análises estatísticas dos dados de hematócrito $(\mathrm{Ht}, \%)$ e de hemoglobina $(\mathrm{Hg}, \mathrm{g} / \mathrm{dl})$ dos leitões suplementados com altos niveis de $\mathrm{Cu}$ e $\mathrm{Zn}$ na ração.

A8 Análises estatísticas dos dados de proteína total $(\mathrm{Pt}$, $\mathrm{g} / \mathrm{dl}$ ) e de albumina (Alb, g/dl) dos leitóes suplementados com altos níveis de $\mathrm{Cu}$ e $\mathrm{Zn}$ na ração.

A9 Análises estatísticas dos dados de globulina (Glo, g/dl) e da relação albumina/globulina (Alb/Glo) dos leitőes suplementados com altos niveis de $\mathrm{Cu}$ e $\mathrm{Zn}$ na ração 61

A10 Análises estatísticas dos dados de uréia (Ur, mg/dl) dos leitóes suplementados com altos niveis de Cu e $\mathrm{Zn}$ na ração .62 


\title{
EFEITOS DA SUPLEMENTAÇÃO DE ALTOS NIVEIS DIETÉTICOS DE COBRE E ZINCO NO DESEMPENHO DE LEITÓES
}

\author{
Autor: NELSON JUÁN PEREIRA MAMANI \\ Orientador: Prof. Dr. VALDOMIRO SHIGUERU MIYADA
}

RESUMO

O presente estudo teve por objetivo avaliar combinaçðes de altos niveis suplementares de cobre e zinco na ração como promotores do crescimento de leitžes recém-desmamados. Foram utilizados 95 animais com $6,7 \pm 1,3 \mathrm{~kg}$ para testar 5 tratamentos: controle; $200 \mathrm{ppm} \mathrm{Cu;} 2.500 \mathrm{ppm} \mathrm{Zn;} 200$ ppm Cu + 2.500 ppm Zn e 100 ppm Cu + 1.250 ppm Zn, na forma de sulfato de cobre e óxido de zinco. Estes microminerais foram incorporados a uma ração basal com 18,89\% PB; 1,07\% lisina e $3.329 \mathrm{kcal}$ EM/kg., constituida de milho, farelo de soja, soro de leite, leite em pó, açúcar, oleo e suplementos minerais e vitamínicos. Durante todo o periodo experimental (28 dias), a raçăo e a água foram fornecidas à vontade. As pesagens individuais dos leitóes e a coleta dos dados de consumo de ração/parcela foram semanais. No final do experimento, após um período de 5 horas de jejum, foram coletadas amostras de sangue dos leitōes para a respectiva determinação dos componentes sanguíneos e plasmáticos. O delineamento experimental utilizado foi o de blocos casualizados incompletos, utilizando um esquema fatorial $3 \times 3$ incompleto, com 6 repetições/tratamento e com 3 ou 4 animais/unidade experimental.

Houve interações $\mathrm{Cu} \times \mathrm{Zn}$ significativas para o ganho diário médio de peso (GDP) nas semanas 1 e $2(P<0,0001)$ e para o consumo diário médio de raçăo (CDR) nas semanas 1 e $2(P<0,0002)$ e semanas 1 a $4(P<0,01)$, sendo que $2.500 \mathrm{ppm}$ de $\mathrm{Zn}$ na auséncia de $\mathrm{Cu}$ suplementar promoveu 
aumentos significativos nas variaveis citadas. $O \mathrm{Zn}$ suplementar na presença de 200 ppm Cu, por um lado, não afetou ( $>>0,05)$ o GDP e o CDR em ambos os periodos, por outro lado, provocou efeitos depressivos na proteína total ( $P<0,0006)$, albumina $(P<0,0001)$ e relação albumina/globulina $(P<0,0009)$. A presença de 200 ppm de Cu na dieta, também monstrou efeitos depressivos nas concentrações de hematócrito ( $P<0,0009)$, e hemoglobina $(P<0,0001)$ independentemente do nivel de $\mathrm{Zn}$ suplementar. Portanto, a adição de um alto nível de $\mathrm{Cu}$ na ração, pode ser indicativo de um possivel efeito tóxico nos animais. Na conversão alimentar média (CA), a presença de $2.500 \mathrm{ppm}$ de $\mathrm{Zn}$ na dieta melhorou $(P<0,004)$ nas primeiras 2 semanas, independentemente do nivel de Cu suplementar.

Ficou evidenciado que a suplementação de 2.500 ppm Zn na ração demonstrou ser um eficiente promotor do crescimento de leitões na fase de creche, tanto nas semanas 1 e 2 como nas semanas 1 a 4 . De modo geral, ficou também constatado, que a combinação intermediária 100 ppm Cu + 1.250 ppm $\mathrm{Zn}$, foi o segundo melhor tratamento em ambos os periodos. 


\title{
EFFECTS OF HIGH DIETARY LEVELS OF COPPER AND ZINC ON PERFORMANCE OF WEANLING PIGS
}

\author{
Author: NELSON JUÁN PEREIRA MAMANI \\ Adviser: Prof. Dr. VALDOMIRO SHIGUERU MIYADA
}

\section{SUMMARY}

An experiment, involving 95 weanling pigs averaging $6.7 \pm 1.3 \mathrm{~kg}$ initial live weight, was carried out to evaluate the effects of high dietary copper and zinc levels: control; 200 ppm Cu; 2,500 ppm Zn; 200 ppm Cu + 2,500 ppm $\mathrm{Zn}$ e $100 \mathrm{ppm} \mathrm{Cu}+1,250 \mathrm{ppm} \mathrm{Zn}$ (as copper sulphate and zinc oxide) on performance and on blood and plasma components. The basal diet $18.89 \%$ CP; $1.07 \%$ lisina and $3,329 \mathrm{kcal} \mathrm{ME} / \mathrm{kg}$ ) was based on corn, soybean meal, dried whey, dried skim milk, sucrose, oil, and fortified with mineral and vitamin supplements. Feed and water were given "ad libitum" to pigs during the 28-day experimental period. Pigs were weighed individually and feed intake/pen was registered weekly. At the end of experimental period, blood samples were collected from anterior vena cava of pigs after a 5-hour fasting period. A randomized complete block design with 6 replications and 3 or 4 animals/experimental unit (pen) were utilized.

Interaction $\mathrm{Cu} \times \mathrm{Zn}$ was observed in the first and second weeks on the average daily gain $(A D G)(P<.0001)$ and on the averge daily feed intake (ADF) $(P<.0002)$. This last variable also showed interaction in these microelements in the first until the fourth week $(P<.01)$, demonstrating that $Z n$, in the absence of supplementary $\mathrm{Cu}$ promoted significant increases on the variables mentioned above. The $\mathrm{Zn}$ supplementation in the presence of 200 ppm Cu did not effect $(P>.05)$ the ADG and ADF in either periods. On the other hand, it showed depressive results of plasma protein $(P<.0006)$, plasma albumin 
$(P<.0001)$ and the relation plasma albumin/globulin $(P<.0009)$. The presence of $200 \mathrm{ppm} \mathrm{Cu}$ in the diet also showed depressive results of hematocrit $(P<.0009)$ and hemoglobin $(P<.0001)$, independently of the level of supplementary $Z n$. Therefore, high dietary level of $\mathrm{Cu}$ is indicating a possible copper toxicity on animals. On feed conversion (FC), the presence of $\mathrm{Zn}$ in the diet improved $(P<.004)$ during the first and second weeks, independently of the level of supplementary $\mathrm{Cu}$.

The results of this experiment suggest that $2,500 \mathrm{ppm} \mathrm{Zn}$ in the absence of supplementary $\mathrm{Cu}$ demonstrated to be an efficient promotor of weanling pigs as in the first and second weeks as in the first until the fourth week. There are, also, evidences that the second best results in general was the $100 \mathrm{ppm} \mathrm{Cu}+1,250 \mathrm{ppm} \mathrm{Zn}$ combination in either periods. 


\section{INTRODUÇÃO}

A suinocultura industrial no mundo, visando aumentar a eficiéncia da produção, adota hoje em dia uma desmama precoce dos leitōes. Quanto mais jovens os animais forem desmamados, maiores serão os desafios, tanto para o animal como para os produtores. É claro que o aumento da eficiência na produção só será possível com a adoção de novas tecnologias geradas pela pesquisa cientifica.

O uso de substáncias antimicrobianas em diversos paises, incluindo o Brasil, visa aumentar a produtividade suina e o número de animais bem desenvolvidos. Muitos são os fatores que podem afetar a resposta, como por exemplo o produto usado, o nivel da substancia, as combinações dos proautos, periodo de fornecimento, composição da ração, idade dos animais, condições climáticas, peso e outros fatores, implicando que cada pais ou região deve gerar sua própria tecnologia.

De acordo com trabalhos anteriores, pode-se verificar claramente 0 efeito positivo do cobre $(\mathrm{Cu})$ como promotor do crescimento em leitőes desmamados. O nivel mais apropriado situa-se entre 150 a 250 ppm. Niveis acima de $250 \mathrm{ppm}$ de $\mathrm{Cu}$ em geral mostraram possiveis efeitos tóxicos nos animais. Foi também observado que a adiçăo de óxido de zinco nas dietas de suínos após o desmame causa melhoras significativas no desempenho destes animais, sendo que nestes casos as doses recomendadas têm variado entre 2.400 a $3.000 \mathrm{ppm}$ de $\mathrm{Zn}$. Niveis superiores a $3.000 \mathrm{ppm}$ de $\mathrm{Zn}$ foram excessivos e não necessários para máxima resposta dos animais. Neste 
mesmo contexto, alguns estudos usando combinações $\mathrm{Cu}+\mathrm{Zn}$ na ração demostraram que a suplementação de $\mathrm{Zn}$ diminui a concentração do $\mathrm{Cu}$ e $\mathrm{Fe}$ nos animais.

O objetivo do trabalho foi o de avaliar a suplementação de altos niveis de cobre e zinco na ração como promotores do crescimento de leitões em recria. A avaliação se baseou nos resultados de performance (ganho diário de peso, consumo diário de raçăo e conversão alimentar), componentes sanguíneos (hematócrito e hemoglobina) e componentes plasmáticos (proteína total, albumina, globulina, relação albumina/globulina e uréla). 


\section{REVISÃO DE LITERATURA}

\subsection{Metabolismo e funções metabólicas do cobre}

A absorção do cobre ocorre principalmente na parte anterior do intestino delgado, onde $\mathrm{opH}$ do conteúdo ainda é ácido. A disponibilidade deste micromineral depende da forma química. O sulfeto, carbonato e o óxido de cobre são fontes cujo cobre é menos disponivel do que o sulfato (Bowland et al.,1961). A maioria do cobre fecal (90 a 95\%) é procedente do alimento presente na dieta que não é absorvido, mas uma parte é oriundo da bile, que é a via principal de excreção do $\mathrm{Cu}$. Este micromineral está largamente ligado às proteinas, não sendo facilmente excretado na urina (Harper et al., 1982; Hays \& Swenson, 1984).

Em pesquisas realizadas com cobre marcado $\left({ }^{64} \mathrm{Cu}\right)$, ficou demostrado que este micromineral é encontrado grandemente associado a fraçz̃es albumínicas do plasma, imediatamente após sua ingestão. Por outro lado, ocorre uma queda na radioatividade plasmática à medida que o Cu ligado à albumina-distribui-se nas cuproproteínas no figado e outros orgãos. Uma elevação secundária na radioatividade plasmática ocorre a seguir, à medida que - Cu incorporado na ceruloplasmina hepática é liberado para o sangue (Miller et al., 1979; Harper et al., 1982).

O cobre é um constituinte essencial de várias proteínas, como as metaloenzimas, e alguns pigmentos de ocorrência natural. Também é importante para a síntese de hemoglobina, formação natural dos ossos, 
queratinização e manutenção da mielina no sistema nervoso (Harper et al., 1982; Lehninger, 1990).

É importante ressaltar que o Cu está presente em 2 enzimas chaves do metabolismo aeróbico: a citocromo c oxidase, que é responsável pela maior parte do oxigénio consumido pelos seres vivos, e a enzima do citosol superóxido - dismutase, que desdobra cataliticamente o radical livre tóxico, íon superóxido $\left(\mathrm{O}_{2}^{-}\right)$, gerado durante o metabolismo aeróbico. Por outro lado, proteínas idênticas à superóxido dismutase foram inicialmente isoladas de fontes diversas e, na ausência de funções enzimáticas conhecidas, receberam uma diversidade de nomes inclusive eritrocupreína (extraída de hemácias), hepatocupreína (do figado) e cérebro cupreína (do cérebro) (Miller et al., 1979; Harper et al., 1982). Após uma acentuada redução do $\mathrm{Cu}$ em leitões recémnascidos, foi observado anemia e ruptura aórtica nos animais, devido a baixa atividade da enzima lisil oxidase, e hipertrofia cardiaca, causada pela baixa atividade da enzima citocromo $\mathrm{C}$ oxidase (Hill et al., 1983; Malinowska, 1988 e Pond et al., 1990).

Segundo Hays \& Swenson (1984), o Cu está presente no plasma sanguíneo associado a uma proteína plasmática carreadora do mesmo, denominada eritrocupreína (superoxido-dismutase), sendo que praticamente todo o cobre plasmático está ligado a esta proteína. A eritrocupreína fornece uma ligação entre o Cu e o metabolismo do Fe. Por outro lado, a oxidaçăo do ion ferroso para a forma férrica é aumentada em 10 a 100 vezes pela açăo da eritrocupreina, dependendo das demandas de ferro nos orgãos eritropoiéticos. A eritrocupreina atua como mediador na liberação do Fe a partir da ferritina e hemossiderina.

A ceruloplasmina, é outra proteína plasmática ligadora de $\mathrm{Cu}$ que contém $0,34 \%$ de $\mathrm{Cu}$ ou cerca de 8 átomos de $\mathrm{Cu}$ por mol, sendo que o plasma normal contém em torno de $30 \mathrm{mg}$ dessa proteina/dl. Acredita-se pois que ela atue como uma enzima ferroxidase durante o metabolismo do ferro (Harper et 
al., 1982). Outras enzimas cuproproteinicas presentes nos tecidos animais incluem a amino-oxidase, a tirosinase, a uricase, ácido ascórbico oxidase e a dopamina-hidroxilase (Harper et al., 1982; Hays \& Swenson, 1984).

\section{2. Metabolismo e funções metabólicas do zinco}

A absorçăo do zinco ocorre principalmente no intestino delgado, especialmente no duodeno (Harper et al., 1982). No entanto, este micromineral tem baixa absorçåo (Hays \& Swenson, 1984). Portanto, a quantidade que deve ser fornecida pelo suplemento é muito maior do que a necessidade metabólica, pois, diferentes pesquisadores, estimaram a necessidade metabólica do suíno em apenas 3 a 4 ppm, enquanto são necessários 30 a 40 ppm, ou niveis maiores, na presença de ácido fítico no alimento, para evitar a ocorrência de paraqueratose e permitir o crescimento normal dos animais.

O zinco dietético é absorvido após formar um complexo com um ligante secretado pelo pâncreas para o lúmen intestinal. 0 controle homeostático do zinco no organismo pode ser exercido, em parte, através da regulação da absorção por meio desse mecanismo (Harper et al.,1982).

O zinco, ingerido ou injetado, é excretado principalmente nas fezes, sendo que a maior parte deste micromineral procede do alimento que não foi absorvido. Para alcançar o equilibrio deste elemento no organismo animal, ocorre excreções pancreáticas que contêm carboxipeptidase e também diminuição na quantidade absorvida. Por outro lado, a excreção urinária de zinco aumenta quando agentes quelantes, tais como 0 ácido etileno diamino tetracético (EDTA) săo ministrados em combinações com o zinco (Hays \& Swenson, 1984).

Quando o zinco está em excesso na alimentação, há uma grande quantidade absorvida a qual não é excretada na mesma proporçăo, fazendo com que este elemento se acumule mais rápido no sangue, páncreas, fígado, 
rins e baço (Harper et al., 1982; Bafundo et al., 1984 e Hahn \& Baker, 1993). O citossol hepático contém proteínas ligantes de zinco e de cobre, idênticas a metalotioneina, que além de sua função na detoxificação celular de metais pesados, podem ainda servir como um meio de armazenamento do zinco (Harper et al., 1982). As quantidades maiores de $\mathrm{Zn}$ no organismo como reserva estão depositadas nos ossos contrariamente as de $\mathrm{Fe}$ e $\mathrm{Cu}$, que estão depositadas no figado (Harper et al., 1982; Wedekind et al., 1994).

São conhecidas mais de $\mathbf{8 0}$ enzimas que requerem zinco como parte dos seus grupos prostéticos. Elas incluem, a anidrase carbónica, carboxipeptidase, fosfatase alcalina, desidrogenase láctica e a desidrogenase glutåmica (Harper et al., 1982; Hays \& Swenson, 1984; Lehninger, 1990). As funçб̃es primordiais do $\mathrm{Zn}$ parecem estar relacionadas ao processo fundamental de replicação celular e expressão gênica, bem como no metabolismo dos ácidos nucléicos e aminoácidos (Hays \& Swenson, 1984). O zinco é importante na síntese de RNA que está presente no citoplasma, assim como nos nucléolos e cromossomas do núcleo, sendo fundamental para o crescimento das células somáticas e germinativas.

A insulina forma complexo com o $\mathrm{Zn}$ tornando possível a utilização da insulina cristalina preparada mediante purificação. O zinco que combina a molécula de insulina aumenta a duração da ação da insulina quando administrada por injeção. Os complexos-insulina estăo também presentes nas células $\beta$ do páncreas e existem evidéncias sugerindo que o zinco é usado nessas células para armazenar e liberar a insulina à medida que é necessário (Harper et al., 1982; Hays \& Swenson, 1984). Por outro lado, entre outras funçőes, o Zn é importante também para manter o balanço ácido-base e o sistema imunológico do organismo (Hahn \& Baker, 1993). 


\section{3. Efeitos de altos níveis de cobre suplementar como promotores do crescimento em suínos}

Inicialmente é necessário considerar que o óxido de cobre (CuO) apesar de ser mais concentrado $(75 \% \mathrm{Cu})$ do que o sulfato de cobre $\left(\mathrm{CuSO}_{4}\right)$ ( $25 \% \mathrm{Cu}$ ), o cobre na forma de óxido demonstrou ser inefetivo como promotor do crescimento. Levando em conta os depósitos de $\mathrm{Cu}$ no figado, a biodisponibilidade de $\mathrm{Cu}$ como $\mathrm{CuO}$ parece ser muito baixa, devido a sua insolubilidade. Diante disto, o óxido de $\mathrm{Cu}$, não é usado como a melhor fonte de Cu suplementar na mistura mineral ou como promotor do crecimento para suinos (Cromwell et al., 1989). O sulfato de cobre por outro lado, demonstrou ser a fonte mais eficiente de Cu na dieta de suínos. Filgueiras et al. (1996), discorda em parte dos resultados anteriores, onde suplementando fontes de cobre como sulfato de $\mathrm{Cu}(25,4 \%)$, sulfato de $\mathrm{Cu}(26 \%)$ e óxido de $\mathrm{Cu}(75 \%)$ em niveis de 0 ; $100 ; 200$ e $400 \mathrm{ppm}$ de cada uma das fontes testadas, encontraram que o óxido de $\mathrm{Cu}(75 \%)$ a $400 \mathrm{ppm}$ proporcionou melhor ganho de peso nos leitб́es. A biodisponibilidade das fontes sulfato foram semelhantes e superiores a fonte óxido.

A fonte Cu-lisina (cobre orgånico), quando injetada em leitões recém-desmamados demonstrou ser mais eficiente como promotor do crescimento do que sulfato de $\mathrm{Cu}$ na dieta. Este fato sugere que o cobre pode atuar melhor a nivel sistêmico. Portanto, futuras pesquisas sobre cobre como promotor do crescimento deveriam concentrar-se visando incrementar a eficiência deste elemento na circulaçăo do que melhorar a atividade antimicrobiana (Zhou et al.,1994).

De acordo com a revisão de trabalhos publicados nos Estados Unidos, Wallace (1967) verificou que suínos de diferentes categorias responderam à suplementação de altos niveis de $\mathrm{Cu}$ (sulfato de cobre) na dieta, variando de 50 a 375 ppm. Niveis acima de 250 ppm foram excessivos e não 
necessários para máxima resposta. O nivel mais apropriado situa-se entre 125 e 250 ppm. Para leitões na fase inicial, as respostas à suplementação de 250 ppm de $\mathrm{Cu}$ (sulfato de cobre) na raçăo foram mais significativas.

Nesta mesma linha, Braude (1975) compilou os resultados de 119 experimentos publicados durante o periodo 1965-1975, tornando possível a comparação da performance entre suínos ministrados com zero ou 250 ppm de $\mathrm{Cu}$ suplementar na dieta. Os altos niveis de $\mathrm{Cu}$ ministrados aos animais, nas diferentes categorias, mostraram um incremento médio de $9,1 \%$ no ganho de peso e $7,4 \%$ na conversão alimentar.

Menten (1988), por sua vez, compilou 17 experimentos realizados nos Estados Unidos no período de 1980 a 1988, para avaliar a influência de altos niveis de cobre na dieta sobre a performance de suínos na fase inicial, tendo sido testados mais de mil animais. As vantagens na performance destes leitões foram $17,9 \%$ no ganho de peso e $7,0 \%$ na conversão alimentar. Cromwell $^{1}$, citado por Menten (1995), em 12 experimentos realizados na Universidade de Kentucky no periodo de 1978 a 1983, analisando respostas à suplementação de 250 ppm de Cu (sulfato de cobre) na raçăo de leitōes na fase inicial, mostraram que houve incrementos de $24,0 \%$ no ganho de peso e $9,7 \%$ na conversão alimentar.

Trabalhos desenvolvidos nos últimos anos com altos niveis de $\mathrm{Cu}$ na dieta de suínos desmamados evidenciaram clararnente o efeito positivo do $\mathrm{Cu}$ como promotor do crescimento dos leitões, quando utilizado em niveis de 150 a 250 ppm. (Burnell et al., 1988; Menten et al., 1988; 1989; 1990; Walker \& Danielson, 1988; Cromwell et al., 1989; Kornegay et al., 1989; Shurson et al., 1990; Dove \& Ewan, 1990; Possobon, 1991; Dove \& Haydon, 1992; Radecki et al., 1992; Rothe et al., 1994; Zhou et al.,1994).

\footnotetext{
${ }^{1}$ CROMWELL, G.L. Antimicrobial agents. In:MILLER, E. R.; ULLREY, D. E. e LEWIS, A. J., ed. Ewine Nutrition. Butterword-Heineman, Stneham, MA. 1991. p.297 - 314
} 
Por outro lado, na literatura existem pesquisas mostrando efeitos tóxicos sobre altos niveis de Cu nas dietas. Assim, Wallace et al. (1960) suplementando $250 \mathrm{ppm}$ de $\mathrm{Cu}$ nas dietas apresentaram resultados sobre toxicoses em suínos desmamados. O nivel de $200 \mathrm{ppm} \mathrm{Cu}$ não exerceu efeitos nocivos sob a performance dos animais, mas niveis de hemoglobina $(\mathrm{Hb})$ foram significativamente reduzidos. Niveis de 100 a 150 ppm de $\mathrm{Cu}$ geralmente não foram tóxicos. Năo foram obtidos crescimentos significativos de leitões e economia do alimento em nenhum dos niveis de suplementação do Cu. Numa avaliaçăo total dos resultados, o referido autor concluiu que não se justifica a suplementação de altos niveis de $\mathrm{Cu}$ na ração de suínos em crescimento e terminação. Neste mesmo contexto, Luecke et al. (1963) e Mello et al. (1972), também, encontraram efeitos negativos no desempenho de leitóes na fase de crescimento com a suplementaçăo de altos niveis de $\mathrm{Cu}$ na dieta.

A suplementação de $\mathrm{Cu}(250 \mathrm{ppm})$ na dieta de porcas durante gestação e lactação demonstrou que não tem efeito detrimental sobre a performance reprodutiva, ao contrário, aumentam os leitões nascidos e os pesos ao desmame (Cromwell et al., 1993). No entanto, a taxa de sobrevivência de leitões não é clara devido às alterações na composição e/ou rendimento do leite das porcas (Thacken, 1991).

\subsection{Efeitos de altos niveis de zinco suplementar como promotores do crescimento em suínos}

Em princípio é importante considerar que nem toda fonte de zinco é eficaz como promotor do crescimento nos animais. Em suínos, consumos farmacológicos de zinco (provenientes de $\mathrm{ZnSO}_{4}$, lisina- $\mathrm{Zn}$ e metionina- $\mathrm{Zn}$ ), incrementam a concentração no plasma mais do que ZnO (Hahn \& Baker, 1993). Trabalhos realizados com frangos indicam que a metionina- $\mathrm{Zn}$ mostrou uma maior disponibilidade de $\mathrm{Zn}$ do que $\mathrm{ZnSO}_{4}$, enquanto que este último 
mostrou ser mais disponivel do que ZnO (Wedekind \& Baker, 1990; Wedekind et al., 1992). A grande bioeficácia da metionina-Zn com relação ao $\mathrm{ZnSO}_{4} \mathrm{em}$ frangos, sugere que o metabolismo de metionina- $\mathrm{Zn}$ difere do metabolismo de Zn procedentes de fontes inorgânicas (Wedekind et al., 1992).

Em suínos em crescimento e terminação, fontes de $\mathrm{Zn}$ testadas por Wedekind et al. (1994) mostraram que o $\mathrm{ZnSO}_{4}$ tem mais zinco biodisponivel do que $\mathrm{ZnO}$ ou lisina- $\mathrm{Zn}$. Da mesma maneira, a biodisponibilidade do $\mathrm{ZnSO}_{4}$ no mesmo experimento foi numericamente mais disponivel do que metionina- $\mathrm{Zn}$. Este resultado discorda dos resultados obtidos em estudos com frangos, indicando que as fontes de $\mathrm{Zn}$ orgânicas em suínos não são mais biodisponíveis de $\mathrm{Zn}$ quando comparado ao $\mathrm{ZnSO}_{4}$ (inorgánico).

Nesta mesma linha, Lima et al. (1996a), testaram quatro fontes de óxido de zinco (Puro para análise - PA e 3 comerciais), fornecendo 2.400 ppm Zn e uma dieta sem zinco suplementar, ao longo de duas semanas do período experimental (28 dias). Este micromineral melhorou 0 desempenho independentemente da fonte. Por outro lado, o $\mathrm{Zn}$ foi eficiente no controle da diarréia, com variações entre as fontes, sendo que o óxido de zinco PA o mais eficiente.

A suplementação de altos níveis de zinco em dietas de suínos após - desmame tem sido estudada como um fator que afeta positivamente o desempenho dos animais e previne a ocorrência de diarréia. As doses recomendadas têm variado entre 2.400 a 3.000 ppm de $\mathrm{Zn}$ provenientes do $\mathrm{ZnO}$. Desta maneira, Holm (1990); Menten et al. (1992); Hahn \& Baker (1993); Miyada et al. (1993), verificaram que a suplementação com altos niveis de $\mathrm{ZnO}$ (3.000 ppm Zn na ração) durante 2 semanas após o desmame, reduziu a mortalidade e a diarréia e aumentou significativamente o desempenho em suínos, sem sinais de intoxicação aparente.

Os resultados obtidos por Lima et al. (1993a), estão de acordo com os resultados anteriores, onde 0 alto nivel suplementar de 2.400 ppm de zinco 
(proveniente do óxido de zinco), fornecido nos primeiros 14 ou 21 dias após o desmame, resultou em melhor ganho de peso e reduziu a ocorréncia de diarréia durante os 23 dias pós-desmame. Neste mesmo contexto, Lima et al. (1993b) avaliaram os efeitos de níveis suplementares de zinco $(0,800,1.600,2.400$ e $3.200 \mathrm{ppm}$ ) nas dietas de suínos desmamados, fornecidos até $\circ 14^{\circ} \mathrm{dia}$, e observaram que o uso de 2.400 a 3.200 ppm de $\mathrm{Zn}$ reduziu a ocorrência de diarreia em relação ao controle. Esses autores também estimaram que a suplementação de $1.793 \mathrm{ppm}$ de zinco na ração, foi suficiente para garantir máximo desempenho dos leitões, até 28 dias após o desmame.

Miyada et al. (1994) testaram niveis de $0,750,1.500,2.250$ e $3.000 \mathrm{ppm}$ de $\mathrm{Zn}$, em leitões de 36 dias de idade, durante 28 dias de experimento. O máximo GDP e a melhor CA foram obtidas com 2.403 e 1.618 ppm de $\mathrm{Zn}$ respectivamente. Os resultados mostraram que os efeitos benéficos são bem evidentes nas duas primeiras semanas. Os autores também indicaram que há indicios que até $2.250 \mathrm{ppm}$ de $\mathrm{Zn}$ a performance dos leitōes foi melhorada em quaisquer períodos. A partir da $3^{\text {a }}$ semana, houve uma piora na performance dos animais recebendo $3.000 \mathrm{ppm}$ de $\mathrm{Zn}$, podendo ser indicativo de um possivel efeito tóxico.

Os resultados obtidos por Botelho et al. (1995), concordam com o trabalho anterior, onde utilizando os mesmos niveis de $\mathrm{Zn}$ na dieta, encontraram que, nas duas semanas iniciais, o nivel 3.000 ppm de $\mathrm{Zn}$ aumentou o GDP em $86 \%$, o CRD em $36 \%$ e CA em $21 \%$ relativamente ao controle. Nas semanas 1 a 4, $2.250 \mathrm{ppm} \mathrm{Zn}$ resultou em maior GDP (33\%) o maior CDR (28\%), não havendo efeito sobre a CA. O uso prolongado de $3.000 \mathrm{ppm} \mathrm{Zn}$ parece ter efeito negativo sobre os animais.

Bertol \& Brito (1993a), utilizando os níveis de 0-0, 3.000-0, 3.0001.500 e 3.000-3.000 ppm de zinco suplementar nas dietas, fornecidas de 0 a 21 e 22 a 42 dias após o desmame, respectivamente, observaram que o fornecimento de 3.000 ppm de 0 a 21 dias e a sequéncia 3.000-1.500, de 0 a 42 
dias, proporcionaram reduções na incidência de diarréia, mortalidade por doença do edema e melhor desempenho dos leitões.

Miyada et al. (1996) testaram os efeitos de níves de zinco dietético suplementar e períodos de fornecimento sobre o desempenho de leitőes em recria, para o qual usaram 5 tratamentos que consistiram em: ração basal (controle), contendo $100 \mathrm{ppm} \mathrm{Zn}$ fornecida durante todo período experimental de 28 dias; ou basal suplemetada com 2.250 ppm Zn por 28 dias; ou 3.000 ppm Zn durante os primeiros 14 dias e 0 ppm nos últimos 14 dias; ou 3.000 ppm Zn durante os primeiros 14 dias e 1.500 ppm nos últimos 14 dias; ou 3.000 ppm Zn durante os primeiros 7 dias e 1.500 ppm nos últimos 21 dias. A adição de elevados niveis de $\mathrm{Zn}$, em dietas iniciais proporcionou efeitos benéficos no desempenho de leitões, mesmo com o fornecimento por um período de 14 dias pós desmame. O período de fornecimento de $\mathrm{Zn}$ suplementar não influenciou a performance dos animais. Maiores niveis de hematócrito e hemoglobina foram obtidos com a suplementação de 2.250 ppm. Com relaçăo aos componentes plasmáticos Botelho et al. (1995), utilizando os niveis $0 ; 750 ; 1.500 ; 2.250$ e 3.000 ppm de $\mathrm{Zn}$ em leitões recém-desmamados, observaram maiores niveis de proteína total e albumina com a suplementação $1.500 \mathrm{ppm}$ de $\mathrm{Zn}$ na dieta.

Bertol \& Brito (1992) verificaram que o nível 3.000 ppm de $\mathrm{Zn}$ (óxido de zinco) proporcionou melhor desempenho do que $250 \mathrm{ppm}$ de $\mathrm{Cu}$ (sulfato de cobre) do desmame até $15,0 \mathrm{~kg}$ de peso vivo e que a incidência de diarréia de 0 a 21 dias após desmame foi semelhante com ZnO e CuSO . Esses autores também indicaram que o uso da alimentaçăo à vontade proporcionou melhor desempenho do desmame até $15 \mathrm{~kg}$ de peso vivo, enquanto que o uso de restrição alimentar provocou redução na incidência de diarréia de 0 a 21 dias pós-desmame.

Quando duas dietas (simples ou semi-complexa) foram suplementadas em leitões com 3 niveis de zinco $(0 ; 1.750 ; 2.400$ ppm) na forma 
de óxido de zinco, durante 14 dias após o desmame, a interaçăo nivel de zinco $x$ tipo de dieta não foi significativa. O zinco suplementar melhorou o desempenho somente nos 14 dias após o desmame, sendo que apenas o ganho de peso foi melhorado no período total do experimento (Lima et al., 1996b).

Brito et al. (1993) estudaram "in vitro" a ação inibitória do óxido de zinco, associado ou não com sulfato de cobre e sulfato ferroso, sobre vinte amostras de Escherichia coli, isoladas de diferentes casos de diarréia pós desmame. Os referidos autores observaram que o ZnO exerceu uma ação inibitória sobre as amostras desta bactéria, e que a toleråncia das amostras de $E$. coli para o ZnO é variável. Não foram observadas inibições competitivas quando se associou $\mathrm{ZnO}, \mathrm{CuSO}_{4}$ e $\mathrm{FeSO}_{4}$ em diferentes concentrações de cada uma das fontes minerais.

Visando determinar os niveis de $\mathrm{Zn}$ nos órgãos e na carne, suínos desmamados com 2 semanas de idade, foram alimentados com uma dieta contendo $3.500 \mathrm{mg} / \mathrm{kg}$ de $\mathrm{Zn}$. No abate, concentraçōes de $\mathrm{Zn}$ em amostras de figados, rins e músculos esqueléticos foram comparadas com amostras de suínos năo suplemntados com $\mathrm{Zn}$ e foram encontradas somente diferenças muito pequenas. (Holm, 1994). Por outro lado, este mesmo autor comenta que os niveis de $\mathrm{Zn}$ na carne para consumo humano atualmente está sendo discutido.

2.5. Interações afetando a absorção e o metabolismo do cobre e do zinco

Quando altos niveis de Cu são ministrados aos animais, devem ser consideradas interações com outros nutrientes dietéticos (Bradley et al., 1983). Altas doses de cobre na dieta provoca redução das reservas de $\mathrm{Fe}$ no fígado, traduzindo-se em uma diminuição do hematócrito e hemoglobina no sangue dos 
animais (Bunch et al., 1963; Ritchie et al., 1963; Kline et al., 1972; Hedges \& Kornegay, 1973; Gipp et al., 1974; Lima et al., 1981; Roof \& Mahan, 1982; Bradley et al., 1983; Malinowska, 1988; Shurson et al., 1990; Dove \& Haydon, 1991; Possobon, 1991; Zhou et al., 1994). Contudo, os estudos demostraram que altos niveis de $\mathrm{Cu}$ (até $250 \mathrm{ppm}$ ), em geral, melhoraram a performance dos animais. A diminuiçăo dos componentes sanguineos nestes casos tem sido considerada pela toxidez do $\mathrm{Cu}$, sendo que, na realidade, pode ser causada pela deficiência de ferro.

O efeito antagónico do $\mathrm{Cu}$ com o Fe pode ocorrer por competiçăo em sitios de ligação principalmente na absorção a nível intestinal, que causa uma diminuição na absorção do ferro. Consequentemente, pode-se verificar uma diminuição dos niveis deste mineral no soro, nos rins e no baço dos animais (Hedges \& Kornegay, 1973).

Alguns trabalhos indicam que a suplementação do $\mathrm{Cu}$ não afeta 0 metabolismo do Fe nos animais. Assim, Zhou et al. (1994) demonstraram que o $\mathrm{Cu}$, aumenta a performance sem afetar a concentração do Fe nos leitōes. Por outro lado, Gipp et al. (1974), injetando Fe (radioativo) no sangue de suinos suplementados com altas doses de $\mathrm{Cu}$, observaram uma metabolização normal deste mineral, concluindo que o transporte e a utilização do Fe não são afetados pelo $\mathrm{Cu}$.

A suplementação de altos niveis de Zn (4.000 a 7.500 ppm) na dieta de ratos elevou a concentração deste mineral no figado e ocacionou uma redução significativa de $\mathrm{Cu}$ e $\mathrm{Fe}$ neste órgão, assim como também uma diminuição da hemoglobina no sangue. Este fato explica a diminuição da performance dos animais quando se usa niveis tóxicos de zinco na dieta (Cox \& Harris, 1960; Magee \& Matrone, 1960; Settlemire \& Matrone, 1967b).

0 efeito do $\mathrm{Zn}$ sobre o metabolismo do Fe parece estar principalmente relacionado com a incorporaçăo do ferro à ferritina, assim como menor absorção deste micromineral a nível de trato intestinal (Settlemire \& 
Matrone, 1967a; 1967b). No entanto, Magee \& Matrone (1960) demonstraram que 0 uso de $\mathrm{Fe}$ radioativo em ratos não fol afetado significativamente na absorção quando houve suplementação com altas doses de $\mathrm{Zn}$ na dieta. Mas doses de $7.500 \mathrm{ppm} \mathrm{Zn}$ parecem interferir na utilização deste mineral, porque a distribuição do Fe marcado no organismo dos animais testados foi diferente aos dos animais controle.

Numa tentativa de aumentar a eficiência do uso do ferro suplementar em leitões recém desmamados, Hackenhaar (1995) utilizou níveis crescentes de $\mathrm{Fe}$ na ração suplementada com altos níveis de $\mathrm{Cu}+\mathrm{Zn}$. Os resultados demonstraram que o uso de altos níveis de $\mathrm{Fe}$ não afetou a performance nem os componentes sanguíneos dos animais. Porém, ocorreu uma tendência de queda na performance dos suínos, à medida que aumentava o nivel de suplementação de $\mathrm{Fe}$ na forma de sulfato ferroso. No entanto, outros pesquisadores (Prince et al., 1979; Lima et al., 1981) observaram que o sulfato ferroso suplementar na ração com alto nível de $\mathrm{Cu}$ induziu uma diminuição do Cu no fígado e aumentou a resposta do crescimento nos animais. Por outro lado, níveis de hemoglobina foram incrementados pela adição de $\mathrm{Fe}$ em dietas contendo 250 ppm de Cu (Dove \& Haydon, 1991).

Existe ampla evidência para suportar a hipótese de que o $\mathrm{Zn}$ está relacionado com a diminuição do efeito tóxico do Cu (Magee \& Matrone, 1960; Shurson et al., 1990). Desta forma, o fornecimento de altas doses de $\mathrm{Zn}$ na dieta pode causar uma redução da concentração de Cu no figado (Starcher, 1968; Underwood, 1977), que pode ser devido a uma diminuição da absorção do $\mathrm{Cu}$ a nivel de trato intestinal. Fischer et al. (1983), demonstraram que o $\mathrm{Zn}$ interfere na absorção do Cu pela sintese induzida de metalotioneina, a qual separa ao cobre dentro da mucosa celular, fazendo-o nảo disponivel para a transferência. Porém, estudos anteriores (Magee \& Matrone, 1960) utilizando Cu radiativo em animais suplementados com altas doses de zinco não encontraram efeitos significativos sobre absorção do $\mathrm{Cu}$, mas sim sobre a sua utilização, 
demonstrando que o $\mathrm{Cu}$ no fígado foi diminuido em $34 \%$ e a excreção deste mineral na urina foi superior com $109 \%$ em relação ao controle.

Hill et al. (1983), Malinowska (1988) e Pond et al. (1990), alimentando porcas durante a gestação com altos níveis de zinco (5.000 ppm), conseguiram produzir uma marcada deficiência de $\mathrm{Cu}$ em leitões recém nascidos. Entretanto, Ritchie et al. (1963) e Luecke et al. (1963), estudando o efeito combinado entre cobre e zinco na alimentação de suínos, não observaram sintomas de toxidez quando suplementaram à dieta com 250 ppm $\mathrm{Cu}+100$ ppm Zn. Mas a suplementação só de $250 \mathrm{ppm} \mathrm{Cu}$ na dieta produziu intoxicação evidenciada com baixos niveis de hemoglobina, alta incidéncia de cirrose hepática e alguns casos de morte. É importante salientar que quando 100 ppm de $\mathrm{Zn}$ foi adicionado às rações suplementadas com $\mathrm{Cu}$, houve um incremento na taxa de crescimento, mas as combinaçǒes $(\mathrm{Cu}+\mathrm{Zn})$ não foram melhores do que a suplementação somente com Zn na dieta (Ritchie et al., 1963).

A biodisponibilidade dos microminerais parece ser afetada por um grande número de fatores dietéticos, incluindo o nivel da proteína dietética. Assim, há indicios que uma baixa concentração proteica na dieta de ratos reduz a absorção do Zn e aumenta a excreção endógena deste micromineral (Van Campen \& House, 1974). Por outro lado, o baixo nivel de proteína dietética, também induz ao decréscimo das concentraçōes de zinco no plasma, fígado e intestino delgado. Estes resultados indicam que uma diminuição da concentração de proteina na dieta pode acarretar uma deficiência de Zn nos animais. Porém, segundo Bunch et al. (1961) e Edmonds et al. (1985), o nivel de proteína na ração não afetou a resposta dos suínos suplementados com alto nivel de Cu.

Os aminoácidos histidina e cistina são conhecidos por afetar o metabolismo dos microminerais no organismo. Estes aminoácidos estāo envolvidos no transporte normal de Cu e Zn (Lau \& Sarkar, 1971). Dentro deste contexto, Harvey et al. (1981) demonstraram que ratos suplementados com $8 \%$ 
de histidina na ração mostram uma diminuiçăo dos niveis de $\mathrm{Zn}$ e Cu no plasma e dos niveis de Cu no figado.

$\mathrm{A}$ adição de $\mathrm{Zn}$ nos animais parece estar relacionada com a ativaçăo da glicogenólise, pois a glicose no soro foi elevada significativamente num periodo de 15 minutos após administraçăo de $\mathrm{Zn}$ por via intraperitonial em ratos (Etzel \& Cousins, 1983). Nestes mesmos animais, efeitos similares sobre glicose no soro foram encontrados quando o zinco foi suplementado por via oral. Os autores concluíram que a diminuição significativa de glicogênio hepático nos animais tratados com $\mathrm{Zn}$ sugere que a glicogenólise foi responsável pelo incremento da glicose no sangue dos animais.

O meio ambiente, genética dos animais e práticas de manejo podem afetar a resposta de performance dos suínos quando suplementados com altos niveis de Cu na raçăo. Assim, quando dietas da mesma composição, com ou sem cobre suplementar, foram ministrados a suinos em crescimento e terminação em 8 estações experimentais, uma interação cobre $x$ estação foi detectada para ganho diário de peso e conversão alimentar (NCR-42, 1974). Por outro lado, $\mathrm{O} \mathrm{Cu}$ pode ser associado com melhoramento na utilização de ácidos graxos não saturados (Dove, 1993). Nesta mesma linha, Dove \& Haydon (1992) desmostraram que a adição de $250 \mathrm{ppm}$ de $\mathrm{Cu}$ em dietas de suínos desmamados contendo gordura animal, aumenta a taxa do crescimento, particularmente durante os primeiros 14 dias pós-desmame. 


\section{MATERIAL E MÉTODOS}

\subsection{Local e animais}

O presente estudo foi conduzido no setor de Suinocultura do Departamento de Zootecnia, da Escola Superior de Agricultura "Luiz de Queiroz", Universidade de São Paulo, Piracicaba-SP. As instalações possuiam gaiolas metálicas suspensas, de 1,50 × 1,20 m, com piso parcialmente ripado, equipadas com comedouros e bebedouros automáticos e aquecedores (lâmpadas infravermelhas de 250 watts) que foram ligados quando a temperatura na sala era inferior a $28^{\circ} \mathrm{C}$.

Foram utilizados 95 leitões desmamados aos $28 \pm 3$ dias de idade das raças Landrace, Large White, Wessex, Duroc ou mestiços dessas raças. Esses leitões, machos castrados e fêmeas, tinham um peso médio inicial de $6,7 \pm 1,3 \mathrm{Kg}$ e foram distribuídos considerando o peso, sexo e a raça aos tratamentos.

\subsection{Ração basal e tratamentos}

A composição percentual da ração basal e o cálculo dos nutrientes são mostrados na Tabela 1. 
Tabela 01 - Composição percentual da raçăo basal.

\begin{tabular}{|c|c|}
\hline INGREDIENTES & $(\%)$ \\
\hline Milho & 56,2 \\
\hline Farelo de soja (46\%PB) & 26,0 \\
\hline Leite em pó desnatado & 5,0 \\
\hline Soro de leite & 5,0 \\
\hline Açúcar & 4,0 \\
\hline Óleo & 1,0 \\
\hline Fosfato Bicálcico & 1,5 \\
\hline Calcário & 0,6 \\
\hline Sal & 0,5 \\
\hline Premix Vitamínico ${ }^{a}$ & 0,1 \\
\hline Premix Mineral $^{b}$ & 0,1 \\
\hline Lisina. $\mathrm{HCl}(78 \%)$ & 0,04 \\
\hline \multicolumn{2}{|l|}{ Valores calculados: } \\
\hline Proteina bruta, $\%$ & 18,89 \\
\hline Lisina, \% & 1,07 \\
\hline Lactose, \% & 5,80 \\
\hline Cálcio, \% & 0,81 \\
\hline Fósforo, \% & 0,65 \\
\hline Energia Metabolizável, kcal/kg. & 3.329 \\
\hline
\end{tabular}

- Suprindo as seguintes quantidades por $\mathrm{kg}$ de ração: vit. A, $12.000 \mathrm{UI}$; vit.D3, 1.500 UI; vit. E,15 UI; vit.K3, $3 \mathrm{mg}$; tiamina, $2 \mathrm{mg}$; riboflavina, $4 \mathrm{mg}$; piridoxina, $4 \mathrm{mg}$; cianocobalamina, $20 \mathrm{mcg}$; niacina, $20 \mathrm{mg}$; pantotenato de calcio, 15 mg; ácido fólico, 0,6mg; biotina, $0,1 \mathrm{mg}$; cloreto de colina, $100 \mathrm{mg}$; bacitracina de żnco, $20 \mathrm{mg}$; metionina, $100 \mathrm{mg}$; L-lisina, $300 \mathrm{mg} ; \mathrm{BHT}, 10 \mathrm{mg}$ e selénio, $0,1 \mathrm{mg}$.

b Suprindo as seguintes quantidades por $\mathrm{kg}$ de raçăo: $\mathrm{Mn}, 40 \mathrm{mg} ; \mathrm{Fe}, 100 \mathrm{mg} ; \mathrm{Zn}, 100 \mathrm{mg} ; \mathrm{Cu}, 10 \mathrm{mg} ; \mathrm{Co}, 1 \mathrm{mg}$ e 1, 1,5 mg. 
Os tratamentos experimentais consistiram em:

T1: Ração basal (controle);

T2: Ração basal +200 ppm de cobre $\left(0,786 \mathrm{~g}\right.$ de $\mathrm{CuSO}_{4} .5 \mathrm{H}_{2} \mathrm{O}$ / kg de ração);

T3: Ração basal +2.500 ppm de zinco $(3,25 \mathrm{~g}$ de $\mathrm{ZnO} / \mathrm{kg}$ de ração);

T4: Ração basal +200 ppm de cobre $\left(0,786 \mathrm{~g}\right.$ de CuSO $_{4} .5 \mathrm{H}_{2} \mathrm{O}$ $/ \mathrm{kg}$ de ração) +2.500 ppm de zinco $(3,25 \mathrm{~g}$ de $\mathrm{ZnO} / \mathrm{kg}$ de ração);

T5: Ração basal $+100 \mathrm{ppm}$ de cobre $\left(0,393 \mathrm{~g}\right.$ de $\mathrm{CuSO}_{4} .5 \mathrm{H}_{2} \mathrm{O}$ $/ \mathrm{kg}$ de raçăo $)+1.250 \mathrm{ppm}$ de zinco $(1,63 \mathrm{~g}$ de $\mathrm{ZnO} / \mathrm{kg}$ de ração).

O delineamento experimental utilizado foi 0 de blocos casualizados. Os tratamentos constituiram um fatorial $3 \times 3$ incompleto o que também pode ser considerado fatorial $2 \times 2$ com um tratamento adicional. Este delineamento possibilita medir a curvilinearidade de resposta a dois fatores com um só ponto adicional, sem a necessidade de usar os 9 tratamentos que são necessários num fatorial $3 \times 3$. É importante salientar que, quando um dos fatores mostra uma resposta curvilinea, o contraste resultará significativo. Neste caso, não se sabe qual dos fatores é o que tem resposta significativa. Este delineamento é evidentemente adequado para estudos preliminares (Box \& Hunter, $1957^{2}$ citado por Cochram \& Cox 1957; Salvarrey, 1997).

As 6 repetições/tratamento foram feitas no tempo, num periodo de 5 meses, de acordo com a disponibilidade de animais. As unidades experimentais foram constituidas de 4 animais no bloco 1 e de 3 animais nos blocos $2,3,4,5$ e 6 .

${ }^{2}$ BOX, G. E. P.; HUNTER, J.S. Multifactor experimental designs. Ann. Math. Stat. 28, 1957. 
3.3 Manejo e colheita de dados

Durante todo o período experimental (28dias), as rações na forma farelada e a água foram fornecidas à vontade. As pesagens individuais dos leitões e a coleta dos dados de consumo de ração/gaiola (parcela) foram feitas semanalmente. A conversão alimentar foi obtida a partir do consumo total de raçăo e do ganho de peso total de cada unidade experimental.

Ao final de cada repetição do experimento os animais foram submetidos a um jejum de 5 horas, com a finalidade de coletar amostras de sangue de 2 animais/unidade experimental (10 amostras/bloco). As amostras de $10 \mathrm{ml}$ foram coletadas da veia cava anterior. O sangue coletado em seringas molhadas com solução ácido etileno-diamino-tetracético (EDTA) a $10 \%$ era transferido em dois tubos de ensaio: num tubo continha $0,10 \mathrm{ml}$ de EDTA $10 \%$ que serviu para homogeneizar com $3 \mathrm{ml}$ de sangue, no outro tubo sem EDTA transferia-se $7 \mathrm{ml}$ de sangue. Desta última amostra, por centrifugação a $3.000 \mathrm{x}$ g por 15 minutos, obteve-se o plasma sanguíneo. Em seguida, preparou-se amostras compostas misturando os plasmas (em volumes equivalentes) dos animais que pertenciam a cada unidade experimental.

As amostras compostas de plasma e as amostras individuais de sangue com EDTA $10 \%$, foram mantidas sob refrigeração até um tempo máximo de 4 horas e, depois, enviadas para o laboratorio Prevlab - Centro de Patologia Clínica Preventiva Ltda., Piracicaba - SP, onde foram feitas as análises dos componentes sanguíneos e plasmáticos. A hemoglobina foi determinada pelo método de cianometahemoglobina e o hematócrito pelo método de microcentrifugação. A fração uréia foi determinado pelo método enzimático automatizado, a proteina total pelo método biureto-colorimétricoautomatizado, a albumina mediante o método verde de bromocresolcolorimétrico automatizado. 0 valor das globulinas foi obtido por meio de cálculo, subtraindo-se o valor da proteína total da albumina (Miyada, 1987). Os 
componentes plasmáticos foram analisados utilizando o equipamento RA 1.000 - Technicon o qual é um analisador bioquímico. Este equipamento processa as amostras com pipetagem automática com método de realização colorimétrico e/ou cinético enzimático.

\subsection{Análises estatísticas.}

Os dados de performance (GDP, CDR, CA) e componentes sanguíneos $(\mathrm{Ht}, \mathrm{Hb})$ e plasmáticos (Pt, Alb, Glo, Alb./glo e Ur.) foram analisados mediante o procedimento GLM de SAS (SAS Institute, 1985). Alguns dados apresentados acima de 5 na CA não foram considerados na análise estatística, por que se encontrabam fora da distribuição normal (ver Tabela A1 do apéndice). Para todas as variáveis indicadas se utilizou o seguinte modelo:

$$
y_{i j k}=\mu+\beta_{j}+\alpha_{i}+\gamma_{k}+\alpha \gamma k i+\varepsilon_{i j k}
$$

onde:

- $\mu$ é a média geral dos dados;

- $\beta_{\mathrm{j}}$ é o efeito do bloco $\mathrm{j}, \mathrm{j}=1,2, \ldots, 6$;

- $\alpha_{j}$ é o efeito do nível $\mathrm{i}$ do fator $\mathrm{Zn}, \mathrm{i}=1,2,3$, correpondendo às doses

$$
0,1.250 \text { e } 2.500 \mathrm{ppm} \text {; }
$$

- $\gamma_{k}$ é o efeito do nivel $k$ do fator $\mathrm{Cu}, \mathrm{k}=1,2,3$, correspondendo às doses 0,100 e 200 ppm;

$\bullet \alpha \gamma$ ki é o efeito da interação dos níveis i e k dos fatores $\mathrm{Zn}$ e Cu;

- Eijk é o erro experimental correspondente à observação yijk. 
Os coeficientes dos contrastes para decompor os efeitos dos tratamentos foi realisado conforme explicitado a seguir:

T R A T A M E N T O S

$\begin{array}{lllll}\text { T1 } & \text { T2 } & \text { T3 } & \text { T4 } & \text { T5 }\end{array}$

\begin{tabular}{lccccc}
$\begin{array}{l}\mathrm{Zn}, \mathrm{ppm} \\
\mathrm{Cu}, \mathrm{ppm}\end{array}$ & 0 & 0 & 2.500 & 2.500 & 1.250 \\
& 0 & 200 & 0 & 200 & 100 \\
\hline Efeito $\mathrm{Zn}$ & - & - & + & + & 0 \\
Efeito $\mathrm{Cu}$ & - & + & - & + & 0 \\
Interação $\mathrm{Zn} \times \mathrm{Cu}$ & + & - & - & + & 0 \\
Curvilinearidade & + & + & + & + & -4 \\
\hline Efeito $\mathrm{Zn}$ sem $\mathrm{Cu}$ & +1 & 0 & -1 & 0 & 0 \\
Efeito $\mathrm{Zn}$ com $\mathrm{Cu}$ & 0 & -1 & 0 & +1 & 0 \\
\hline
\end{tabular}

Com a finalidade de estudar o tratamento T5 (100 ppm Cu +1.250 ppm $\mathrm{Zn}$ ) e comparar as médias entre tratamentos também foi utilizado o teste de Tukey ao nivel de $5 \%$ de probabilidade. 


\section{RESULTADOS E DISCUSSÕES}

\subsection{Características de performance}

As características de performance dos leitões foram o ganho diário médio de peso (GDP), consumo diário médio de ração (CDR) e a conversão alimentar média (CA), referentes às semanas 1 e 2 e semanas 1 a 4 (Periodo Total). Estes resultados são apresentados na Tabela 2. Os valores originais dos dados de performance, assim como as análises estatisticas correspondentes, tanto nas duas primeiras semanas como no período total, em função dos altos niveis de zinco e cobre na ração, são mostrados nas tabelas A1, A2, A3, A4 e A5 do Apéndice.

Houve interação $\mathrm{Cu} \times \mathrm{Zn}$ significativas, sendo que $2.500 \mathrm{ppm}$ de $\mathrm{Zn}$ na ausência do $\mathrm{Cu}$ promoveu aumentos no GDP nas semanas 1 e 2 $(P<0,0001)$ e para o CDR nas semanas 1 e $2(P<0,0002)$ e semanas 1 a 4 $(\mathrm{P}<0,01)$, ao paso que, $\circ \mathrm{Zn}$ na presença de $200 \mathrm{ppm}$ de $\mathrm{Cu}$, apresentou respostas năo significativas no GDP e CDR. Na CA năo se detectaram interações $\mathrm{Cu} \times \mathrm{Zn}$ tanto nas semanas 1 e $2(P>0,05)$ como no periodo total $(P>0,05)$. Porém, é importante salientar que a presença do $Z n$ na dieta nas primeiras duas semanas melhorou a CA $(P<0,004)$, indicando que $\circ$ efeito positivo do $\mathrm{Zn}$ nesta variável independe do nivel de $\mathrm{Cu}$ na ração. Estes resultados são ilustrados na figura 1 . 


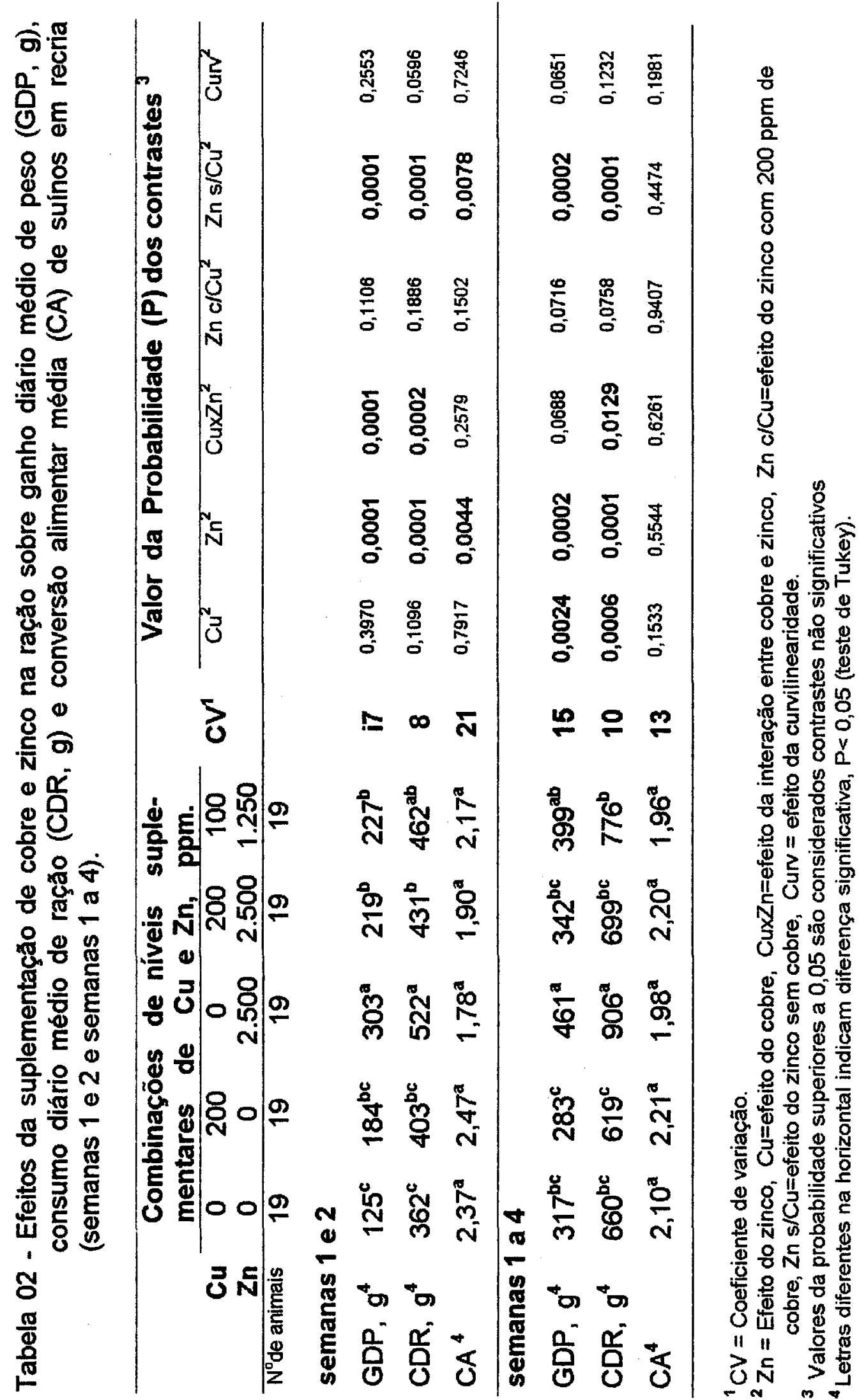




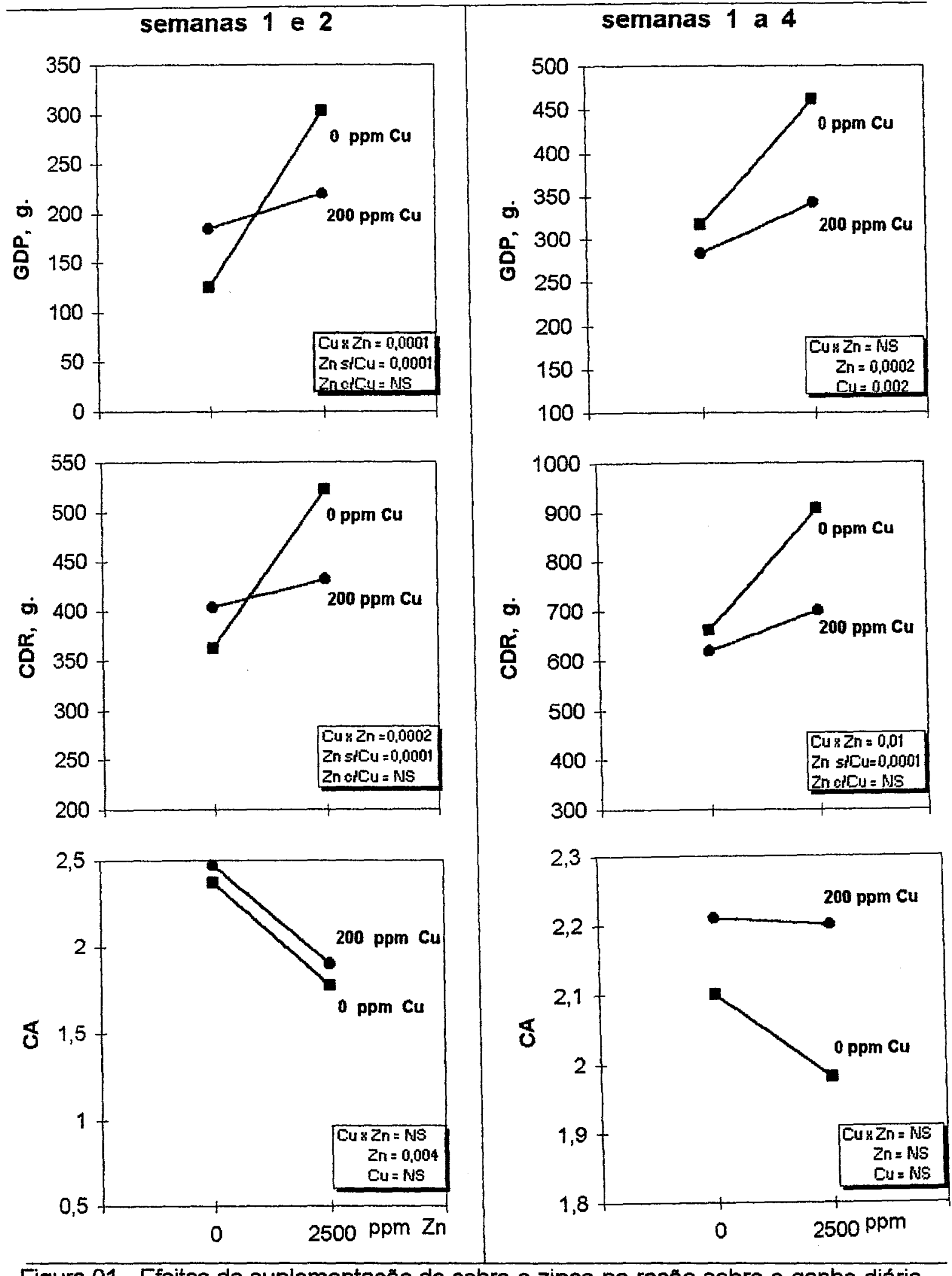

Figura 01 - Efeitos da suplementaçăo de cobre e zinco na raçáo sobre o ganho diário médio de peso (GDP, g), consumo diário médio de raçăo (CDR, g), e conversão alimentar média (CA) de leitões em recria (semanas 1 e 2 e semanas 1 a 4). 
Os resultados deste estudo indicam que a adição de um alto nível de $\mathrm{Cu}$ na ração pode ter um possível efeito tóxico nos animais. A toxicidade, segundo Ritchie et al. (1963), Lillie et al. (1977), e Shurson et al. (1990) pode ocorrer devido a um aumento na concentração de cobre no fígado, com uma concomitante diminuição de ferro no figado e no plasma.

0 aumento no GDP dos leitóes com a suplementação de $\mathrm{Zn}$ na presença de alto nível de Cu na ração foi de $19 \%$ (219 g/dia $\times 184 \mathrm{~g} /$ dia) nas semanas 1 e 2 e $21 \%$ (342 g/dia x $283 \mathrm{~g} /$ dia) nas semanas 1 a 4, ao passo que, - $\mathrm{Zn}$ na ausência de $\mathrm{Cu}$, apresentou respostas adicionais no GDP de $142 \%$ (303 g/dia $\times 125 \mathrm{~g} / \mathrm{dia}$ ) e $45 \%$ (461 g/dia $\times 317 \mathrm{~g} / \mathrm{dia})$ nas semanas 1 e 2 e semanas 1 a 4 , respectivamente.

As respostas adicionais no GDP com a dieta $\mathrm{Zn}$ na ausência de $\mathrm{Cu}$ ocorreram por um lado, em função do aumento no CDR que foi de $44 \%$ (522 $\mathrm{g} / \mathrm{dia} \times 362 \mathrm{~g} / \mathrm{dia})$ nas semanas 1 e 2 e de $37 \%$ (906 g/dia $\times 660 \mathrm{~g} / \mathrm{dia})$ nas semanas 1 a 4 . Por outro lado, o aumento no GDP nas semanas 1 e 2 , também foi contribuido pela melhora $(P<0,004)$ na conversão alimentar de $32 \%(2,42 x$ $1,84)$ com a suplementação de $Z n$ na ração. A suplementação com altos niveis de $\mathrm{Zn}$ na presença de Cu não mostrou uma resposta significativa no CDR, desta maneira o aumento nas primeiras 2 semanas foi de $7 \%$ ( $431 \mathrm{~g} / \mathrm{dia}$ - $403 \mathrm{~g} / \mathrm{dia}$ ) e nas semanas 1 a 4 de $13 \%$ ( $699 \mathrm{~g} / \mathrm{dia}-619 \mathrm{~g} / \mathrm{dia})$.

Os efeitos positivos do $\mathrm{Zn}$ obtidos no presente estudo, confirman trabalhos anteriores (Holm, 1990; Bertol \& Brito, 1992, 1993a, 1993b; Menten et al., 1992; Hahn \& Baker; 1993; Lima et al., 1993a, 1993b, 1996b; Miyada et al.,1993, 1994, 1996; Holm, 1994; Botelho et al.,1995) que demonstraram melhores desempenhos quando os leitőes recebiam doses entre 2.400 a 3.000 ppm de zinco, provenientes do ZnO nas dietas durante as primeiras semanas pós desmame. Estes resultados indicam que o efeito promotor do crescimento dos altos niveis de $\mathrm{Zn}$ na ração é dependente do incremento do CDR e da melhora na CA. 
Os efeitos não significativos do $\mathrm{Cu}$ nas semanas 1 e 2 e nas semanas 1 a 4, não estão de acordo com a maioria dos estudos publicados na literatura (Burnell et al., 1988; Menten, 1988; Menten et al., 1989, 1990; Walker \& Danielson, 1988; Cromwell et al., 1989; Kornegay et al., 1989; Shurson et al., 1990; Dove \& Ewan, 1990; Dove \& Haydow, 1991; Possobon, 1991; Radecki et al., 1992; Rothe et al., 1994; Zhou et al., 1994) que evidenciam claramente o efeito positivo do cobre como promotor do crescimento quando este elemento é suplementado em níveis de 150 a 250 ppm na raçăo de suínos desmamados. Uma explicação para estes resultados contraditórios pode ser devido a raçăo utilizada neste experimento que incluiu leite em pó, soro de leite e óleo, diferentemente dos outros pesquisadores citados acima. Além disso, outros aspectos importantes devem ser considerados como a época de estudo, leitegada de origem e práticas de manejo (NCR-42, 1974) que podem influir na obtenção de resultados diferentes.

Por outro lado é importante salientar que existem pesquisas mostrando efeitos tóxicos quando se usaram altos niveis de $\mathrm{Cu}$ nas dietas. Wallace et al. (1960), suplementando $250 \mathrm{ppm}$ de $\mathrm{Cu}$ nas dietas observaram resultados de toxicose em suínos desmamados. O nivel de $200 \mathrm{ppm} \mathrm{Cu} \mathrm{não}$ exerceu efeitos nocivos sob a performance dos animais, mas niveis de $\mathrm{Hb}$ foram significativamente reduzidos. Niveis de 100 a $150 \mathrm{ppm}$ de $\mathrm{Cu}$ foram geralmente nåo tóxicos. Crescimentos significativos de leitões e economia do alimento não foram obtidos em nenhum dos niveis de suplementação do $\mathrm{Cu}$. Numa avaliaçăo total dos resultados, os autores concluiram que năo se justifica a suplementação de altos niveis de $\mathrm{Cu}$ na ração de suínos em crescimento e terminação. Nesta mesma linha, Luecke et al. (1963) e Mello et al. (1972) encontraram também efeitos negativos no desempenho de leitões na fase de crescimento quando a dieta foi suplementada com altos niveis de $\mathrm{Cu}$.

Năo se detectaram curvilinearidades significativas $(P>0,05)$ em nenhuma das variáveis de desempenho (GDP, CDR e CA), tanto nas semanas 
1 e 2 como nas semanas 1 a 4 . Estas respostas indicam que altos niveis suplementares de $\mathrm{Cu} \times \mathrm{Zn}$ na ração não influenciam as variáveis de desempenho dos leitões. As respostas não significativas da curvilinearidade indicam que o delineamento ( $3 \times 3$ incompleto) usado neste experimento, foi eficiente como estudo preliminar, sem a necessidade de usar os 9 tratamentos que são necessarios num fatorial $3 \times 3$.

A suplementação combinada $100 \mathrm{ppm} \mathrm{Cu}+1.250 \mathrm{ppm} \mathrm{Zn}$, quando comparada ao tratamento controle mediante o teste de Tukey, no GDP foi $82 \%(P<0,05)$ superior nas semanas 1 e 2 e $26 \%(P>0,05)$ nas semanas 1 a 4. Estas respostas incrementadas no GDP ocorreram em função do aumento no CDR que foi de $28 \%$ ( $P<0,05)$, nas primeiras 2 semanas e de $18 \%(P>0,05)$ no periodo total. Essas respostas são ilustradas graficamente nas figuras 2 e 3 . Por outro lado, a suplementação $100 \mathrm{ppm} \mathrm{Cu}+1.250 \mathrm{ppm} \mathrm{Zn}$ quando comparado ao tratamento $200 \mathrm{ppm} C u$ nas semanas 1 a 4 foi $41 \%(P<0,05)$ superior no GDP e $25 \%(P<0,05)$ no CDR. Este fato, pode ser um indicativo de que a suplementação associada $100 \mathrm{ppm} \mathrm{Cu}+1.250 \mathrm{ppm} \mathrm{Zn}$ (níveis intermediários) pode diminuir o efeito tóxico do cobre nos animais no periodo total. Em estudos anteriores, a suplementação de $\mathrm{Zn}$ na dieta reduziu a concentração do $\mathrm{Cu}$ no fígado devido à diminuição na absorçăo deste micromineral ao nivel do trato gastrointestinal (Ritchie et al., 1963; Underwood, 1977 e Shurson et al., 1990). Nesta mesma linha, a suplementação de altos niveis de $\mathrm{Zn}$ (5.000 ppm) nas dietas de porcas em gestação reduziram a quantidade de $\mathrm{Cu}$ e $\mathrm{Fe}$ no figado, causando uma marcada deficiéncia de $\mathrm{Cu}$ em leitões recém-nacidos (Hill et al., 1983; Malinowka, 1988 e Pond et al., 1990). Por outro lado, Luecke et al. (1963), suplementando 250 ppm Cu + 100 ppm Zn na dieta não observaram sinais de toxidez em suínos. Porém, à adição de 200 ppm $\mathrm{Cu}$ produziu uma intoxicação, evidenciada, por baixos niveis de hemoglobina, alto teor de cobre no figado e alguns casos de morte. 


\section{Semanas 1 e 2}

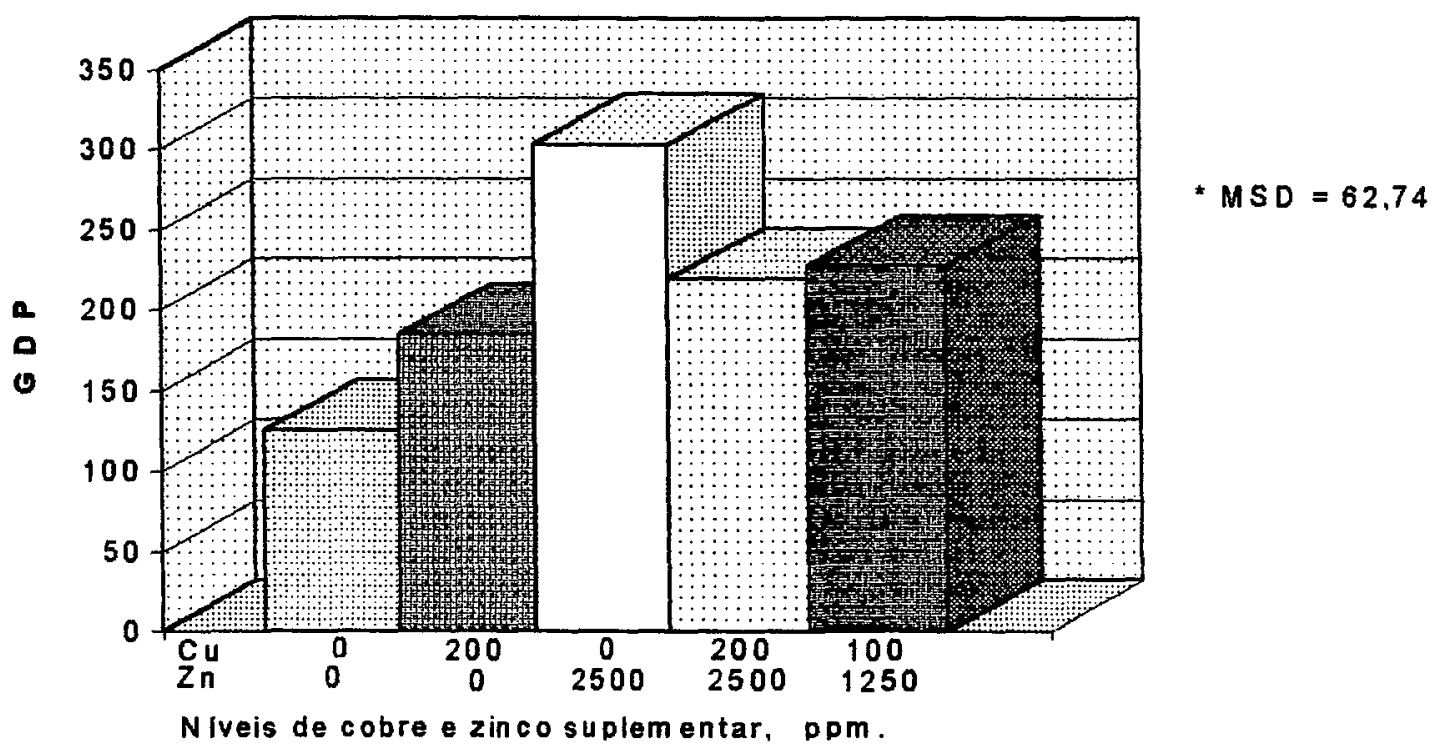

Semanas 1 a 4

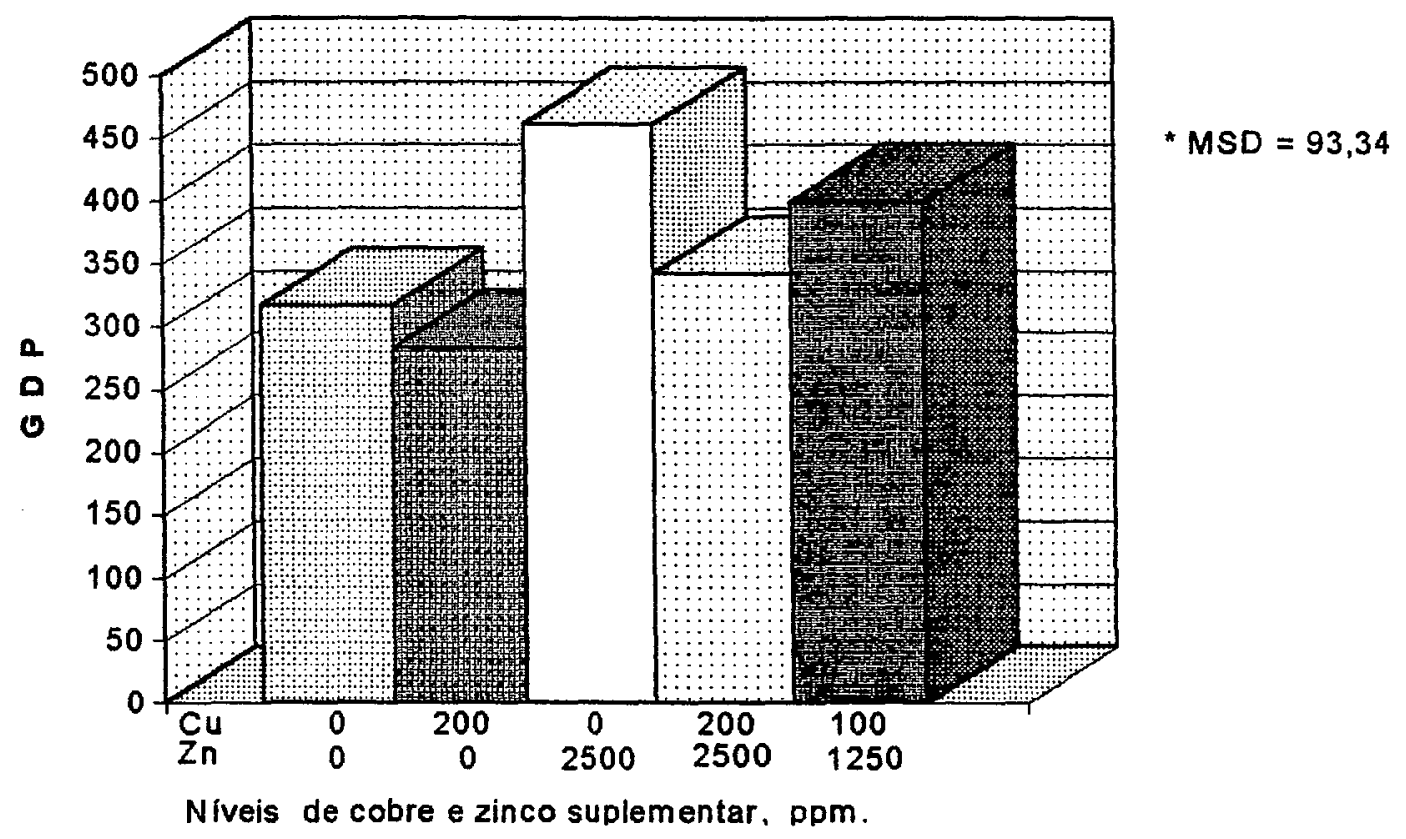

"MSD = Minima diferença significativa pelo teste de Tukey ao nivel de $5 \%$ de probabilidade.

Figura 02 - Efeitos de combinações de altos niveis suplementares de cobre e zinco na ração sobre o ganho diário médio de peso (GDP, g) de leitões em recria (semanas 1 e 2 e semanas 1 a 4 ). 


\section{Semanas 1 e 2}

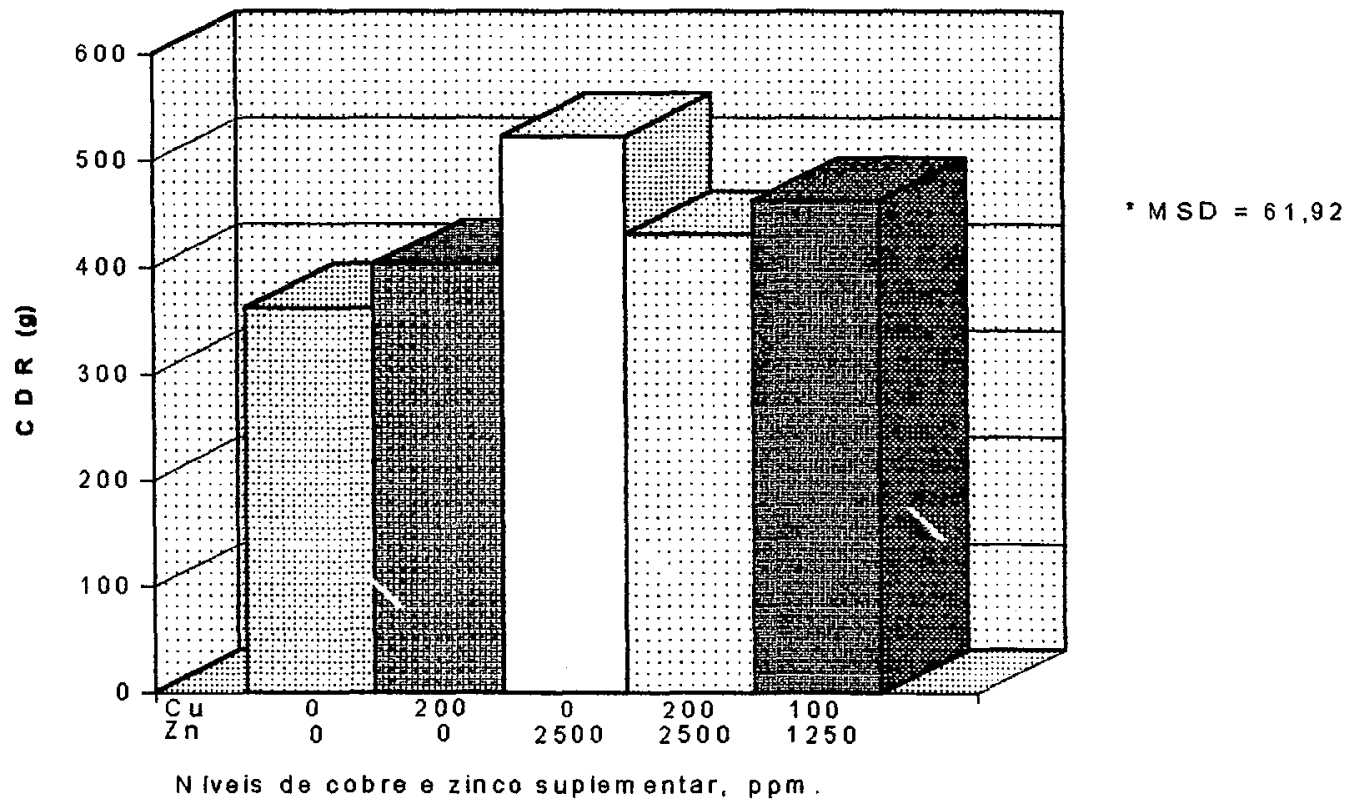

\section{Semanas 1 a 4}

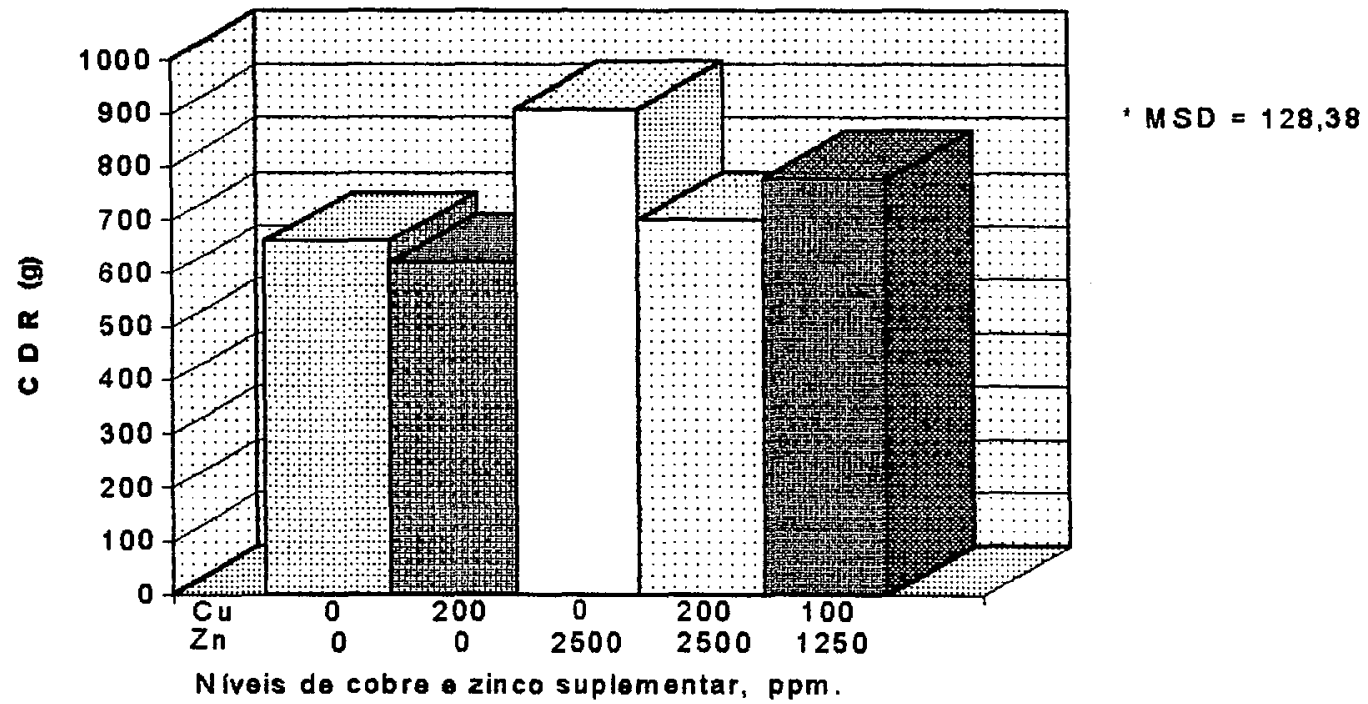

* MSD= Minima diferença significativa pelo teste de Tukey ao nivel de 5\% de probabilidade.

Figura 03 - Efeitos de combinações de altos niveis suplementares de cobre e zinco na ração sobre o consumo diário médio de ração (CDR, g) de leitóes em recria (semanas 1 e 2 e semanas 1 a 4 ). 
De modo geral, os resultados mostram que a adição de 100 ppm

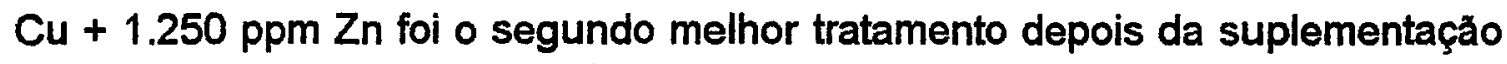
de 2.500 ppm $\mathrm{Zn}$ na ração, tanto nas semanas 1 e 2 como nas semanas 1 a 4 . As vantagens com o tratamento $2.500 \mathrm{ppm}$ de $\mathrm{Zn}$, frente ao tratamento combinado $100 \mathrm{ppm} \mathrm{Cu}+1.250 \mathrm{ppm} \mathrm{Zn}$ nas semanas 1 e 2 foram de 33\% $(P<0,05)$ no GDP e $13 \%(P>0,05)$ no $C D R$. Já no periodo total, as vantagens no CDR foi de $17 \%(P<0,05)$ e $16 \%$ no GDP, sendo esta última não significativa $(P>0,05)$ pelo teste de Tukey.

\subsection{Componentes sanguíneos e plasmáticos}

Os resultados médios dos componentes sanguíneos (hematócrito e hemoglobina) e plasmáticos (proteina total, albumina, globulina, relação albumina / globulina e uréia) dos leitões suplementados com altos niveis de cobre e zinco na dieta, bem como as análises estatisticas são apresentados na Tabela 3. Os dados originais dos componentes sanguíneos e plasmáticos, assim como as análises estatisticas são mostrados respectivamente nas Tabelas A6, A7, A8, A9, e A10 do apéndice.

Não se detectaram interações significativas CuxZn para 0 hematócrito $(\mathrm{Ht})$ e para a hemoglobina $(\mathrm{Hb})$. Porém, é importante salientar que a presença do Cu na ração diminuiu a concentração do $\mathrm{Ht}(\mathrm{P}<0,0009)$ e da $\mathrm{Hb}$ $(\mathrm{P}<0,0001)$, indicando que o efeito depressivo do $\mathrm{Cu}$ nos componentes sanguíneos, independe do nivel de $\mathrm{Zn}$ na ração. Este fato, é indicativo de que, a adição de 200 ppm de $\mathrm{Cu}$ na dieta pode ter um possivel efeito tóxico nos animais. Essas respostas são ilustradas graficamente na figura 4. As médias do $\mathrm{Ht}$ de 31,92 a $36,92 \%$, assim como as médias da $\mathrm{Hb}$ de 9,92 a $11,55 \mathrm{~g} / \mathrm{dl}$ encontradas no presente experimento podem ser cosideradas como normais. Segundo Pond \& Maner (1974) e Miyada (1987), os valores que variam de 34 a $42 \%$ para o $\mathrm{Ht}$ e de 9 a $14 \mathrm{~g} / \mathrm{dl}$ para a $\mathrm{Hb}$ foram considerados como normais. 


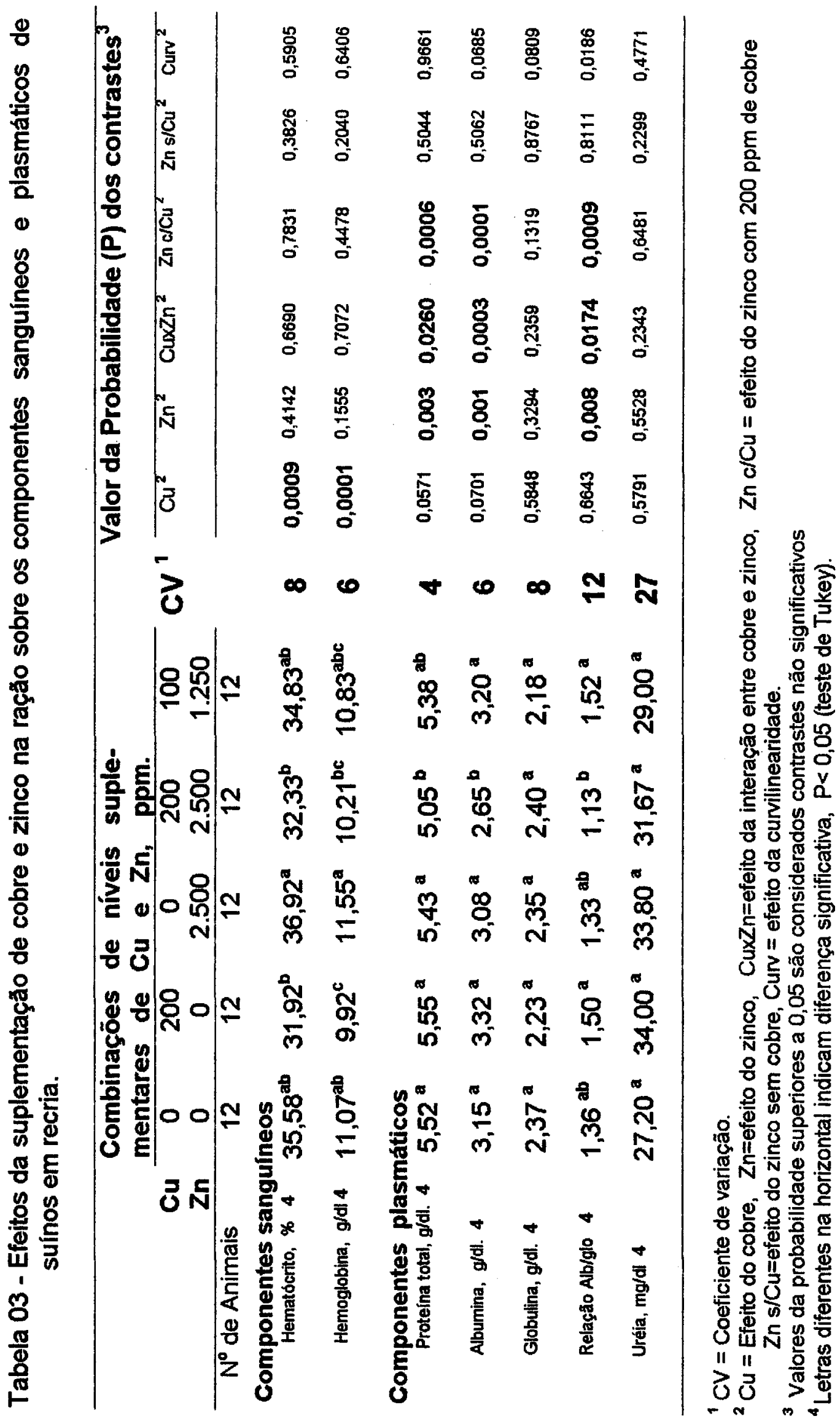


Médias do hematócrito \%

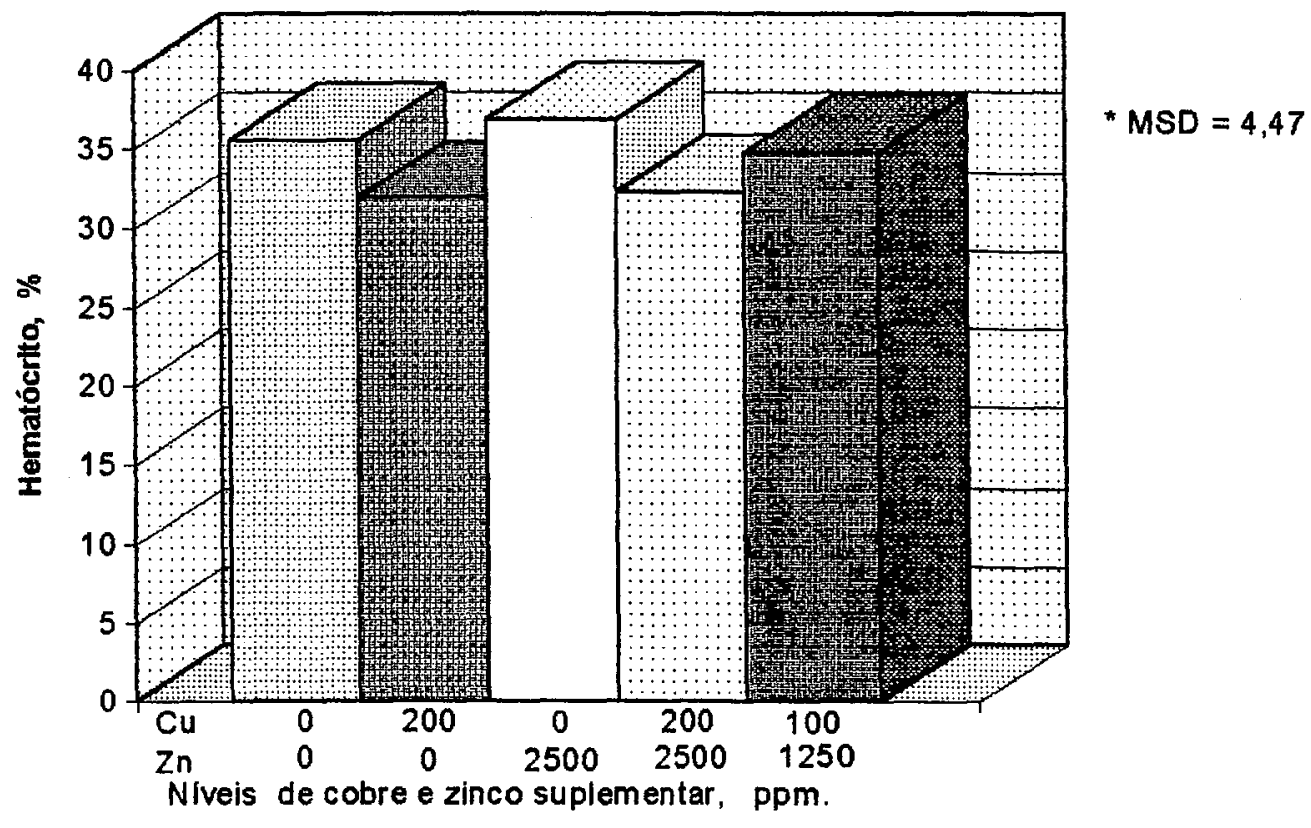

Médias da hemoglobina $\mathrm{g} / \mathrm{dl}$.

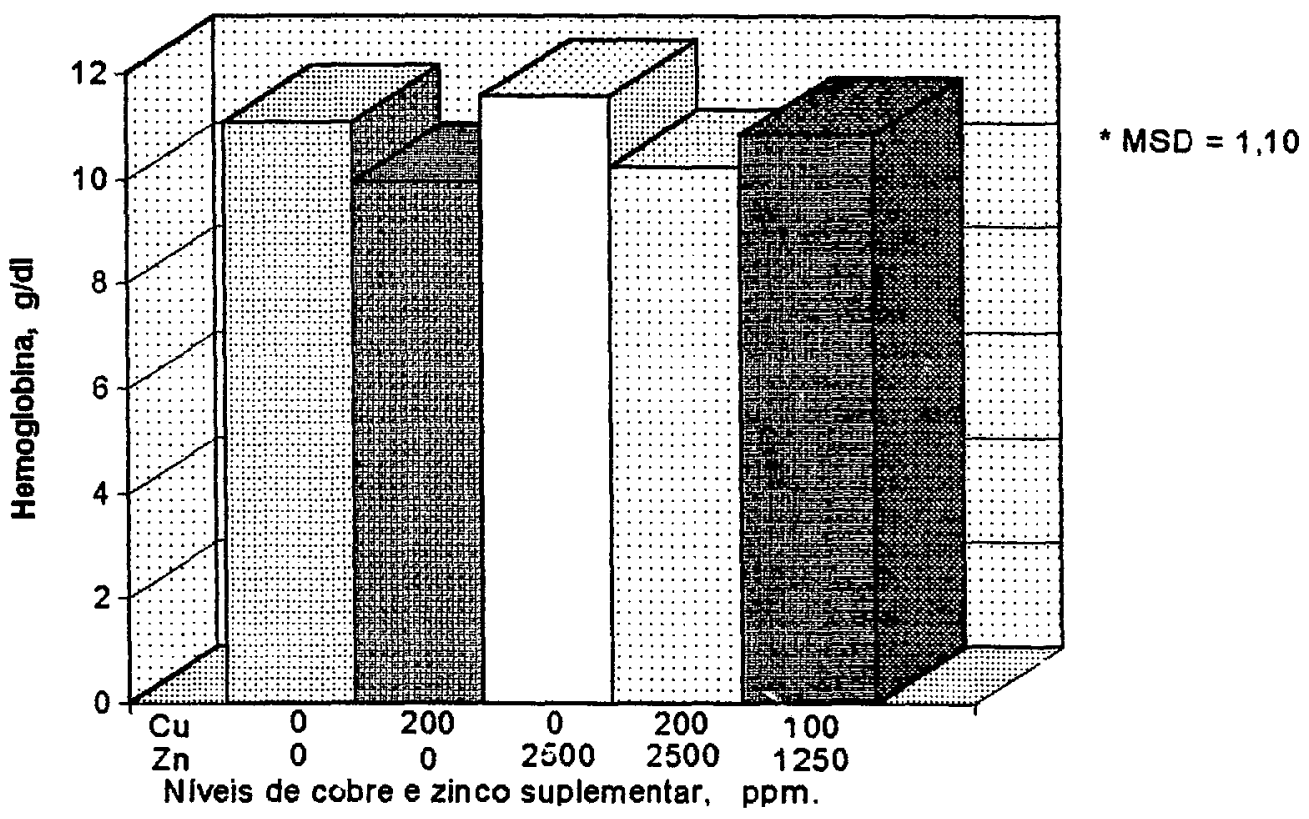

* MSD= Minima diferença significativa pelo teste de Tukey ao nivel de 5\% de probabilidade.

Figura 04 - Efeitos de combinações de altos niveis suplementares de cobre e zinco na raçåo sobre o hematócrito $(\mathrm{Ht}, \%)$ e hemoglobina $(\mathrm{Hb}, \mathrm{g} / \mathrm{dl})$ do sangue dos leitőes em recria. 
Neste mesmo contexto, Wallace et al. (1960), Bunch et al. (1961), Ritchie et al. (1963), Hedges \& Kornegay (1973), Shurson et al. (1990) e Possobon (1991), observaram reduçōes dos conteúdos de $\mathrm{Hb}$ e Ht quando ministraram altas dose de $\mathrm{Cu}$ na dieta. $\mathrm{O}$ presente trabalho concorda com os resultados anteriores. Os referidos autores argumentaram que uma possivel explicaçăo para a redução de $\mathrm{Ht}$ e $\mathrm{Hb}$ pode ser devido à deficiência de ferro induzido pelo alto nivel de cobre no mecanismo de absorçăo a nivel do trato gastrointestinal. Por outro lado, Ritchie et al. (1963) num exame do figado demostraram que a medida que a concentração do Cu aumenta a concentração de Fe diminui. Pond \& Maner (1974) postulam que os niveis dos componentes sanguíneos $(\mathrm{Hb}$ e $H t)$ são indicadores do estado nutricional de ferro nos animais. Consequentemente, no presente experimento, pode-se sugerir que a presença de $200 \mathrm{ppm}$ de Cu na dieta pode ter influido na diminuição dos componentes sanguíneos devido a uma possível deficiência de ferro, acarretando prejuizos na performance dos leitozes.

Considerando os componentes plasmáticos, para a proteina total (Pt), a interaçăo $\mathrm{Cu} \times \mathrm{Zn}$ foi significativa $(P<0,03)$, sendo que o $\mathrm{Zn}$ na presença do $\mathrm{Cu}$ provocou uma diminuição significativa $(P<0,0006)$ na concentração proteica, ao passo que, o $\mathrm{Zn}$ na ausência do $\mathrm{Cu}$ não teve efeitos significativos. Os valores de proteina total entre 5,05 a $5,55 \mathrm{~g} / \mathrm{dl}$ encontrados no presente experimento são relativamente menores aos valores de 5,6 a $5,8 \mathrm{~g} / \mathrm{dl}$ de plasma considerados como normais para leitões com 3 meses de idade (Pond \& Maner, 1974). As variaçżes do nivel de proteina no plasma podem ser devidas a muitos fatores como idade, sexo, estresse, influência hormonal, estado fisiológico e nutricional, embora as mudanças nas proteinas séricas causadas pela nutriçăo sejam lentas e de dificil deteç̧ão e interpretação (Kaneko, 1980).

Com relação ao conteúdo de albumina do plasma dos leitões, a interação $\mathrm{Cu} \times \mathrm{Zn}$ foi significativa $(P<0,0003)$, sendo que a suplementaçăo $\mathrm{Zn}$ na presença de $\mathrm{Cu}$ ocasionou um decréscimo $(P<0,0001)$ na concentração de 
albumina, em relação à suplementação $\mathrm{Zn}$ sem $\mathrm{Cu}$. Os valores médios de albumina encontrados neste estudo incluindo o do tratamento $200 \mathrm{ppm} \mathrm{Cu}+$ $2.500 \mathrm{ppm} Z \mathrm{n}$ (média mais baixa com $2,65 \mathrm{~g} / \mathrm{dl}$ ) estão dentro da faixa de normalidade. Pond e Maner (1974) indicam que o nivel de 2,58 g/dl de albumina sérica para leitões com 3 meses de idade ainda é considerado como normal. Além disso, estes mesmos autores relataram que uma deficiéncia de proteina ou de um aminoácido essencial pode causar uma diminuiçăo de albumina no plasma dos animais. Resultados semelhantes sobre albumina (Berto, 1985; Miyada, 1987; Lopez Preciado, 1990 e Possobon, 1991) também foram encontrados em leitões em recria. Os valores normais deste componente indicam que a ração do presente experimento foi adequada em proteína para os animais desta categoria.

Os niveis de globulina permaneceram praticamente inalterados $(P>0,05)$, independentemente do tratamento. Assim, as concentrações encontradas neste estudo (de 2,18 a $2,40 \mathrm{~g} / \mathrm{dl}$ ) foram semelhantes aos niveis normais encontrados na faixa de 2,19 a 3,00 para leitões em recria (Miyada, 1987; Lopez Preciado, 1990 e Possobon, 1991).

Quanto à relação albumina/globulina, a interação $\mathrm{Cu} \times \mathrm{Zn}$ foi significativa $(P<0,02)$, sendo que o $\mathrm{Zn}$ na presença do $\mathrm{Cu}$ apresentou uma resposta depressiva $(P<0,0009)$, com relação à suplementaçăo de $\mathrm{Zn}$ na ausência de $\mathrm{Cu}$. Com tudo, as médias da relação albumina/globulina na faixa de 1,13 a 1,52 encontradas no presente experimento podem ser consideradas como normais. 0 valor 0,82 da relação albumina/globulina foi considerado como normal para leitões com 3 meses de idade (Pond \& Maner, 1974). Nesta mesma categoria, variaçōes amplas de 0,40 a 1,01 da relação albumina/globulina também foram considerados normais (Miyada, 1987). Para suínos com aproximadamente 2 meses de idade (Miyada, 1987; Lopez Preciado, 1990 e Possobon, 1991) reportaram valores na faixa de 0,9 a 1,60. 
Sabe-se que a relaçăo albumina/globulina pode ser um indicador da nutrição proteica nos suínos. No entanto, Pond \& Maner (1974) relataram que uma moderada deficiência de um aminoácido essencial ou de proteína na ração pode diminuir o nivel de albumina no soro, que ao mesmo tempo pode não alterar o conteúdo da globulina. Provavelmente, a relação albumina/globulina em certos casos pode não ser uma medida segura para avaliar a nutriçăo proteica de leitőes com aproximadamente 2 meses de idade, pois, neste experimento a suplementaçăo de $200 \mathrm{ppm} \mathrm{Cu}+2.500$ ppm Zn, mesmo apresentando uma redução na relação albumina/globulina houve um aumento no desempenho dos leitões. Em pesquisas anteriores, similares resultados foram observados por Miyada (1987) e Possobon (1991).

O conteúdo de uréia no plasma dos leitões não foi influenciado $(P>0.05)$ pela suplementação da ração com altos níveis de $\mathrm{Cu}$ e $\mathrm{Zn}$. Os valores de uréia na faixa de 27 a $34 \mathrm{mg} / \mathrm{dl}$ de plasma encontrados neste experimento săo similares aos observados por Miyada (1987) e Lopez Preciado (1990), nas faixas de 21 a 30 e 27 a 30, respectivamente, em suínos com cerca de 2 meses de idade. Este fato é um indicativo de que a suplementação de altos niveis de $\mathrm{Cu}$ e $\mathrm{Zn}$ na ração não afetou o metabolismo proteíco que pudesse alterar a uréia do plasma nos animais estudados.

Sabe-se que um dos mecanismos de ação dos promotores do crescimento em melhorar a performance dos animais é através de um incremento na incorporaçăo de aminoácidos. Consequentemente, poder-se-ia esperar uma redução significativa da uréia no plasma dos leitz̃es nos tratamentos que aumentaram significativamente a performance. Porém, este fato, năo foi observado no presente estudo. Portanto, esse mecanismo, possivelmente possa não estar envolvido em leitőes nas condiçס̃es do presente experimento. 


\section{CONCLUSÓES}

- Foi verificada interação $\mathrm{Cu} \times \mathrm{Zn}$ significativas para o GDP e CDR nas semanas 1 e 2, e para o CDR no período total. A suplementação de 2.500 ppm de $\mathrm{Zn}$ na ausência de $\mathrm{Cu}$ suplementar promoveu aumentos significativos no GDP e CDR, ao passo que, o Zn suplementar na presença de 200 ppm $\mathrm{Cu}$, não afetou as respostas nas variáveis indicadas.

- A presença de 2.500 ppm de $\mathrm{Zn}$ na dieta melhorou a CA nas primeiras 2 semanas independentemente do nível de Cu suplementar.

- A presença de 200 ppm de Cu na dieta, mostrou efeitos depressivos nas concentrações de hematócrito e hemoglobina independentemente do nivel de $\mathrm{Zn}$ suplementar, indicando que a adição de um alto nivel de $\mathrm{Cu}$ na ração pode proporcionar um possivel efeito tóxico nos animais.

- A combinação intermediária 100 ppm Cu + 1.250 ppm Zn resultou ser o segundo melhor tratamento como promotor do crescimento de leitões, depois do tratamento $2.500 \mathrm{ppm} \mathrm{Zn}$ em ambos os períodos. 


\section{REFERÉNCIAS BIBLIOGRÁFICAS}

BAFUNDO, K.W.; BAKER, D.H.; FITZGERALD, P.R. The iron-zinc interrelationship in chick as influenced by Eimeria acervulina infection. Journal of Nutrition, v.114, p.1306-1312, 1984.

BERTO, D.A. Levedura seca de destileria de álcool de cana de açúcar (Saccharomyces spp.) na alimentação de leitões em recria. Piracicaba, 1985. 133p. Dissertação (Mestrado) -Escola Superior de Agricultura "Luiz de Queiroz", Universidade de São Paulo.

BERTOL, T.M.; BRITO, B G. de. Efeito do óxidu de zinco x sulfato de cobre com ou sem restrição alimentar sobre o desempenho e ocorrências de diarréia em leitōes. In: REUNIÃO ANUAL DA SOCIEDADE BRASILEIRA DE ZOOTECNIA, 29., Lavras, 1992. Anais. Lavras: SBZ, 1992. p.369.

BERTOL, T. M.; BRITO, B.G. de. Efeito da retirada gradual do óxido de zinco da dieta sobre o desempenho e mortalidade por doença do edema em leitões, após desmame. In: CONGRESSO BRASILEIRO DE VETERINÁRIOS ESPECIALISTAS EM SUINOS, 6., Goiânia, 1993. Anais. Goiânia: Abraves, 1993a. p.154. 
BERTOL, T. M.; BRITO, B.G. de. Efeito da redução do nível de proteína da dieta, associada a utilização do óxido de zinco, sobre o desempenho e ocorréncia de diarréia pós-desmame em leitões In: CONGRESSO BRASILEIRO DE VETERINÁRIOS ESPECIALISTAS EM SUINOS, 6. Goiânia, 1993. Anais. Goiånia: Abraves, 1993b. p.155.

BOTELHO, F.G.A.; MIYADA, V.S.; MENTEN, J.F.M. et al. Efeito de altos níveis de zinco suplementar em dietas semi-complexas de leitōes recémdesmamados. In: REUNIÃO ANUAL DA SOCIEDADE BRASILEIRA DE ZOOTECNIA, 32., Brasília, 1995. Anais. Brasília: SBZ, 1995. p.484.

BOWLAND, J.P.; BRAUDE, R.; CHAMBERLAIN, A.G. et al. The absorption, distribution and excretion of labelled copper in young pigs given different quantities, as sulphide orally or intravenously. British Journal of Nutrition, v.15, p.59 - 72, 1961.

BRADLEY, B.D.; GRABER, G; CONDON, R.J. et al. Effects of graded levels of dietary copper on copper and iron concentration in swine tissues. Journal of Animal Science, v.56, p.625-630, 1983.

BRAUDE, R. Copper as a performance promotor in pigs. Copper in farming symposium. Copper Development Association, England, 79-97, 1975.

BRITO, M.A.V.P.; LIMA, G.J.M.M.; BRITO, J.R.F. et al. Açăo do óxido de zinco sobre amostras de Escherichia coli, isoladas de suínos com diarréia pósdesmame. In: CONGRESSO BRASILEIRO DE VETERINÁRIOS ESPECIALISTAS EM SUINOS, 6., Goiânia, 1993. Anais. Goiânia: Abraves, 1993. p.157. 
BUNCH, R.J.; SPEER, V.C.; HAYS, V.W. et al. Effect of high levels of copper and chlortetracycline on performance of pigs. Journal of Animal Science, v.20, p.927 (abstract), 1961.

BUNCH, R. J.; SPEER, V.C.; HAYS, V.W. et al. Effects of high levels of copper and chlortetracycline on performance of pigs. Journal of Animal Science, v.22, p.56-60, 1963.

BURNELL, T.W.; CROMWELL, G.L.; MONEGUE, H.J. Effects of the dietary inclusion of copper sulfate on the growth responses to organic acid in dietas for weanling pigs. Journal of Animal Science, v.66, p.1100-1108, 1988.

COCHRAN, W. G.; COX, G. M. Experimental designs. 2 ed. New York: John Wiley \& Sons, Inc, 1957. 611p.

COX, D.H.; HARRIS, D. Effect of excess dietary zinc on iron and copper in the rat. Journal of Nutrition, v.70, p.514-520, 1960.

CROMWELL, G.L.; MONENGUE, H.J.; STAHLY, T.S. Long-term effects of feeding a high copper diet to sows during gestation and lactation. Journal of Animal Science, v.71, p.2996-3002, 1993.

CROMWELL, G.L.; STAHLY, T.S.; MONEGUE, H.J. Effects of source and level of copper on performance and liver copper stores in weanling pigs. Journal of Animal Science, v.67, p.2996-3002, 1989.

DOVE, C. R. The effect of adding copper and various fat sources to the diets of weanling swine on growth performance and serum fatty acid profiles. Journal of Animal Science, v.71, p.2187-2192, 1993. 
DOVE, C.R.; EWAN, R.C. Effect of excess dietary copper, iron or zinc on the tocopherol and selenium status of growing pigs. Journal of Animal Science, v.68, p.2407-2413, 1990.

DOVE, C.R.; HAYDON, K.D. The effect of copper addition to diets with various iron levels on the performance and hematology of weanling swine. Journal of Animal Science, v.69, p.2013-2019, 1991.

DOVE, C.R.; HAYDON, K.D. The effect of copper and fat addition to the diets of weanling swine on growth performance and serum fatty acids. Journal of Animal Science, v.70, p.805-810, 1992.

EDMONDS, M.S.; IZQUIERDO, O.A.; BAKER, D.H. Feed additive studies with newly weaned pigs: efficacy of supplemental copper, antibiotics and organic acids. Journal of Animal Science, v.60, p.462-469, 1985.

ETZEL, K. R.; COUSINS R.J. Hiperglycemic action of zinc in rats. Journal of Nutrition, v.113, p.1657-1663, 1983.

FILGUEIRAS, E.P.; HOSSAIN, S.M.; BERTECHINI, A.G. Biodisponibilidade de cobre do sulfato e do óxido de cobre para leitões de 10 a $25 \mathrm{~kg}$. In: REUNIÃO ANUAL DA SOCIEDADE BRASILEIRA DE ZOOTECNIA, 33., Fortaleza, 1996. Anais. Fortaleza: SBZ, 1996. p. 133.

FISCHER, P.W. F.; GIROUX, A.; L'ABRE, M.R. Effects of zinc on mucosal copper binding and on the kinetics of copper absortion. Journal of Nutrition, v.113, p. 462-469, 1983. 
GIPP, W.F.; POND,W.G.; KALLFELX, F.A. et al. Effect of dietary copper, iron and ascorbic acid levels on hematology, blood and tissue copper, iron and zinc concentrations and ${ }^{64} \mathrm{Cu}$ and ${ }^{59} \mathrm{Fe}$ metabolism in young pigs. Journal of Nutrition, v.104, p.532-541, 1974.

HACKENHAAR, L. Niveis de ferro, inorgånico ou quelatado, em raçőes iniciais de suínos com altos níveis de cobre e de zinco. Piracicaba, 1995. 73p. Dissertação (Mestrado) - Escola Superior de Agricultura "Luiz de Queiroz", Universidade de São Paulo.

HAHN, J.D.; BAKER, D.H. Growth and plasma zinc responses of young pigs fed pharmacologic levels of zinc. Journal of Animal Science, v.71, p.3020$3024,1993$.

HARPER, H. A.; RODWELL, V.W.; MAYES, P.A. et al. Manual de química fisiológica. 5.ed. São Paulo: Atheneu, 1982. 736p.

HARVEY, P.W.; HUNSAKER, H.A.; ALLEN, K.G.D. Dietary I-histidine - induced hipercholesterolemia and hypocupremia in the rat. Journal of Nutrition, v.111, p.639-647, 1981.

HAYS, V.W.; SWENSON, M.J. Minerais. In: SWENSON, M.J. Dukes fisiologia dos animais domésticos. 10.ed. Rio de Janeiro: Guanabara Koogan, 1984. cap.31, p. 407-408.

HEDGES, J.D.; KORNEGAY, E.T. Interrelationship of dietary copper and iron as measured by bloob parameters, tissue stores and feedlot performance of swine. Journal of Animal Science, v.37, p.1147-1154, 1973. 
HILL, G.M.; KU, P.K.; MILLER, E.R. et al. Copper dificiency in neonatal pigs induced by a high zinc maternal diet. Journal of Nutrition, v.113, p.867$872,1983$.

HOLM, A. E. E. coli associated diarrhoea in weaner pigs: Zinc oxide added to the feed as a preventive mesure?. IPVS, 11, 22 lasane. Proceeding.....p.154. 1990.

HOLM, A. Zinc concentration in the tissues of pigs at slaughter. The addition of zinc oxide to feed. Nutrition Abstracts and Reviews. Ser. B, v.64, n.2, p.114, Feb. 1994.

KANEKO, J. J. Clinical biochemistry of domestic animal. 3.ed. New York: Academic Press, 1980. p.832.

KLINE, R.D.; HAYS, V. W.; CROMWELL, G.L. Related effects of copper, zinc and iron on performance, hematology and copper stores of pigs. Journal of Animal Science, v.34, p.393-396, 1972.

KORNEGAY, E.T.; Van HEUGTEN, P.H.G.; LINDERMANN, M.D. et al. Effects of biotin and high copper levels on performance and inmmune response of weanling. Journal of Animal Science, v.67, p.1471-1477, 1989.

LAU, S.; SARKAR, B. Ternary coordination complex between human serum albumin, copper (II), and I-histidine. Journal of Biological Chemistry, v.246, p.5938-5943, 1971. 
LEHNINGER, A.L. Princípios de bioquímica. São Paulo: Sarvier, 1990. $725 p$.

LILLIE, R. J.;FROBISH, L.T.; STEELE, N.C. et al. Effect of dietary copper and tylosin and subsequent withdrawal on growth, hematology and tissue residues of growing-finishing pigs. Journal of Animal Science, v.45, p.100-107, 1977.

LIMA, F.R. de.; STAHLY, T.S.; CROMWELL, G.L. Effects of copper, with and without ferrous sulfide, and antibiotics on the performance of pigs. Journal of Animal Science, v.52, p.241-246, 1981.

LIMA, G.J.M.M.; MORES, N.; FIALHO, F.B. et al. Período de suplementaçăo de zinco na dieta sobre o desempenho de suínos desmamados. In: CONGRESSO BRASILEIRO DE VETERINÁRIOS ESPECIALISTAS EM SUINOS, 6., Goiânia, 1993. Anais. Goiânia: Abraves, 1993a. p.153.

LIMA, G.J.M.H.; MORES, N.; GUIDONI, A.L. et al. Níveis de suplementação de zinco na dieta sobre 0 desempenho de suínos desmamados. In: CONGRESSO BRASILEIRO DE VETERINÁRIOS ESPECIALISTAS EM SUINOS, 6., Goiånia, 1993. Anais. Goiånia: Abraves, 1993b. p.156.

LIMA, G.J.M.M.; GUIDONI, A.L.; MORES, N. et al. Efeito do uso de diferentes fontes de óxido de zinco em dietas de leitões após o desmame. In: REUNIÃO ANUAL DA SOCIEDADE BRASILEIRA DE ZOOTECNIA, 33., Fortaleza, 1996. Anais. Fortaleza: SBZ, 1996a. p.177. 
LIMA, G.J.M.M.; GUIDONI, A.L.; MORES, N. et al. Efeito do uso de altos niveis de zinco em dietas simples e semi-complexas de leitőes após o desmame. In: REUNIÃO ANUAL DA SOCIEDADE BRASILEIRA DE ZOOTECNIA, 33., Fortaleza, 1996. Anais. Fortaleza: SBZ, 1996b. p.185.

LÓPEZ PRECIADO, L.C. A salinomicina como estimulante do crescimento de suínos em recria. Piracicaba, 1990. 55p. Dissertação (Mestrado) - Escola Superior de Agricultura "Luiz de Queiroz", Universidade de Sảo Paulo.

LUECKE, R.W.; RITCHIE, H.D.; HOEFER, J.A. Copper and zinc in swine feeding. Proceedings of Distillers Feed Research Council, v.18, p.40-43, 1963.

MAGEE, A.C.; MATRONE, G. Studies on growth, copper metabolism and iron metabolism of rats fed high levels of zinc. Journal of Nutrition, v.72, p.233$244,1960$.

MALINOWSKA, A. Synergistic and antagonistic effect of certain major and trace elements in pigs. Medycyna-Veterynary, v.44, p.242-245, 1988.

MELLO, H. V. de.; TÔRRES, C.A.A.; PEREIRA, J.A.A. et al. Sulfato de cobre como estimulante do crescimento de leitões após a desmama. Revista Ceres, v.19, n.105, p.347-357, 1972.

MENTEN, J.F.M. Effects of high dietary copper on the utilization of nutrients and on blood and intestinal variables of starter pigs. Michigan, $1988.122 p$. Thesis (Ph-D)-Michigan State University. 
MENTEN, J.F.M.; KU, P.K.; MILLER, E. R. Efeitos de suplementação de altos niveis de cobre e de biotina na dieta de suinos em recria. In: REUNIÄO ANUAL DA SOCIEDADE BRASILEIRA DE ZOOTECNIA, 26., Porto Alegre, 1989. Anais. Porto Alegre: SBZ, 1989. p.197.

MENTEN, J.F.M.; MIYADA, V.S.; CITRONI, A.R. Suplementaçăo de alto nível de zinco na dieta de leitões. In: REUNIÃO ANUAL DA SOCIEDADE BRASILEIRA DE ZOOTECNIA, 29., Lavras, 1992. Anais. Lavras: SBZ, 1992. p.368.

MENTEN, J.F.M.; MIYADA, V.S.; LAVORENTI, A. Avaliaçăo de diferentes aditivos antimicrobianos como promotores de crescimento de leitões desmamados. In: REUNIÃO ANUAL DA SOCIEDADE BRASILEIRA DE ZOOTECNIA, 27., Campinas, 1990. Anais. Campinas: SBZ, 1990. p.189.

MENTEN, J.F.M. Eficácia, efeito sinérgico e modo de ação de agentes antimicrobianos como promotores do crescimento de suínos. Piracicaba, 1995. 106p. Tese (Livre-Docência) - Escola Superior de Agricultura "Luiz de Queiroz", Universidade de São Paulo.

MILLER, E.R.; STOWE, M.D.; KU, P.K.; HILL, G. M. Copper and zinc in swine nutrition. In: NATIONAL FEED INGREDIENTS ASSOCIATION. Copper and zinc in animal nutrition. lowa: Copyright, 1979. p.1-139.

MIYADA, V.S. A levedura seca na alimentação de suínos: estudos adicionais sobre o seu valor protéico e vitamínico. Piracicaba, 1987. 159p. (LivreDocência) - Escola Superior de Agricultura "Luiz de Queiroz", Universidade de São Paulo. 
MIYADA, V.S.; MENTEN, J.F.M.; BOTELHO, F.G.A. et al. Efeitos de níveis de zinco dietético suplementar a período de fornecimento sobre desempenho de leitōes em recria. In: REUNIÃO ANUAL DA SOCIEDADE BRASILEIRA DE ZOOTECNIA, 33., Fortaleza, 1996. Anais. Fortaleza: SBZ, 1996. p.113.

MIYADA, V.S.; MENTEN, J.F.M.; PACKER, I.U. et al. Avaliaçåo de niveis de crescimentos de zinco dietético suplementar como promotor do crescimento de leitões na fase de creche. In: REUNIÃO ANUAL DA SOCIEDADE BRASILEIRA DE ZOOTECNIA, 30., Rio de Janeiro,1993. Anais. Niterói: SBZ, 1993. p.383.

MIYADA, V.S.; MENTEN, J.F.M.; BEDUSCHI NETO, F. et al. Niveis de zinco dietético suplementar como promotor do crescimento de leitóes na fase de creche. In: REUNIÃO ANUAL DA SOCIEDADE BRASILEIRA DE ZOOTECNIA, 31., Maringá, 1994. Anais. Maringá: SBZ, 1994. p.15.

NCR-42 COMMITEE ON SWINE NUTRITION. Cooperative regional studies with growing swine: effects of vitamin and levels of supplementary copper during the prowing-finishing period on gain, feed conversion and tissue copper storage in swine. Journal of Animal Science. v.39, p.512-520. 1974.

POND, W.G.; MANER, J.H. Swing production in temperate and tropical environments. San Francisco: Freeman, 1974. cap.6: Postnatal development, p.96-120.

POND, W.G.; KROOK, L.P.; KLEVAY, L.M. Bone pathology without cardiovascular lesions in pigs fed high zinc and low copper diet. Nutrition Research, v.10, p.871-885, 1990. 
POSSOBON, R.M. O cobre como estimulante do crescimento de suinos em recria. Piracicaba, 1991. 63p. Dissertaçăo (Mestrado) - Escola Superior de Agricultura "Luiz de Queiroz", Universidade de Såo Paulo.

PRINCE, T.J.; HAYS, V.W.; CROMWELL, G.L. Effects of copper sulfate and ferrous sulfide on performance and liver copper and iron stores of pigs. Journal of Animal Science, v.49, p.507-513, 1979.

RADECKI, S. V.; KU, P.K.; BENNINK, M. R. et. al. Effect of dietary copper on intestinal mucosa enzime activity, morfology, and turnover rates in weanling pigs. Journal of Animal Science, v.70, p.1424-1431, 1992.

RITCHIE, H.D.; LUECKE, R.W.; BALTZER, B.V. et.al. Copper and zinc interrelationships in the pig. Journal of Nutrition, v.79, p.117-123, 1963.

ROOF, M.D.; MAHAN, D.C. Effect of carbadox and various dietary copper levels for weanling swine. Journal of Animal Science, v.55, p.1109-1117, 1982.

ROTHE, S.; GROPP, J.; WEISSER, $H$. et. al. Influence of vitamin $C$ and zinc on copper-induced increased cadmium retention in pigs. Resumo em Nutrition Abstracts and Reviews, Ser. B, v.64, p.840, 1994.

SALVARREY, L. Análisis y diseño de experimentos. Montevideo, 1997, 198p. (no prelo)

SAS INSTITUTE INC. SAS User's guide: statistics, version 5th Ed. Cary, NC: SAS Instituty Inc, 1985. 956p. 
SETTLEMIRE, C.T.; MATRONE, G. In vivo effect of zinc on iron turnover in rats and life span of the erytrocyte. Journal of Nutrition, v.92, p.159-165, $1967 a$.

SETTLEMIRE, C.T.; MATRONE, G. In vivo interference of zinc with ferritin iron in the rat. Journal of Nutrition, v.92, p.153-159, $1967 \mathrm{~b}$.

SHURSON, G.C.; KU, P.K.; WAXLER, G.L. et al. Physiological relationships between microbiological status and dietary copper levels in the pig. Journal of Animal Science, v.68, p.1061-1071, 1990.

STARCHER, B. C. Studies on the mechanism of copper absorption in the chick. Journal of Nutrition, v.97, p.321-326, 1968.

THACKEN, P.A. Effect of high levels of copper or dichlorvos during late gestation and lactation on sow productivity. Canadian Journal of Animal Science, v.71, p.227-232, 1991. /Resumo em CAB Abstracts on CD-ROM, 1988$1991 /$.

UNDERWOOD, E.J. Copper. In: UNDERWOOD, E.J. Trace elements in human and animal nutrition. 4.ed. New York: Academic Press, 1977. p.5699.

Van CAMPEN, D.; HOUSE, W. A. Effect of a low protein diet on retention of an oral dose of zinc and on tissue consentration of zinc, iron, and copper in rats. Journal of Nutrition, v.104, p.84-90, 1974. 
WALKER, G.L.; DANIELSON, D.M. Effect of different copper sulfate levels in nursery diets on weanling pigs performance. Journal of Animal Science, v.66, suppl.1, p.141, 1988.

WALLACE, H.D. High level copper in swine feeding. New York: International Copper Research Association, 1967. 24p.

WALLACE, H.D.; Mc CALL, J.T.; BASS, B.; COMBS, G.E. High level copper for growing-finishing swine. Journal of Animal Science, v.19, p.1153-1163, 1960.

WEDEKIND, K.J.; BAKER, D.H. Zinc bioavailability in feed-grade sources of zinc. Journal of Animal Science, v.68, p.684-689, 1990.

WEDEKIND, K.J.; HORTIN, A. E.; BAKER, D.H. Methodology for assessing zinc bioavailability:: Efficacy estimates for zinc-methionine, zinc sulfate, and zinc oxide. Journal of Animal Science, v.70, p.178-187, 1992.

WEDEKIND, K.J.; LEWIS, A.J. GIESEMANN, M.A. et al. Bioavailability of zinc from inorganic and organic sources for pigs fed corn-soybean meal diets. Journal of Animal Science, v.72, p.2681-2689, 1994.

ZHOU, W.; KORNEGAY, E.T., LIDEMAN, M.D. et. al. Stimulation of growth by intravenous injection of copper in weanling pigs. Journal of Animal Science, v.72, p.2395-2403, 1994. 
APÉNDICE 
Tabela A1 - Resultados da performance dos leitões suplementados com altos niveis de Cu e $\mathrm{Zn}$ na ração (semanas 1 e 2 ).

\begin{tabular}{|c|c|c|c|c|c|c|}
\hline $\begin{array}{l}\text { Niveis de Cu e Zn } \\
\text { na racão }\end{array}$ & Bloco & $\mathrm{PMI}^{*}$ & $\mathrm{PMF}^{*}$ & $\mathrm{CDR}^{*}$ & $\mathrm{GDP}^{*}$ & $C A^{*}$ \\
\hline $\begin{array}{l}\text { T1 } \\
0 \text { ppm }\end{array}$ & $\begin{array}{l}1 \\
2 \\
3 \\
4 \\
5 \\
6\end{array}$ & $\begin{array}{l}6,73 \\
5,87 \\
7,07 \\
7,90 \\
6,67 \\
6,13\end{array}$ & $\begin{array}{c}8,60 \\
7,43 \\
7,40 \\
10,57 \\
9,73 \\
7,10\end{array}$ & $\begin{array}{l}0,348 \\
0,293 \\
0,269 \\
0,440 \\
0,426 \\
0,393\end{array}$ & $\begin{array}{l}0,134 \\
0,112 \\
0,024 \\
0,190 \\
0,219 \\
0,069\end{array}$ & $\begin{array}{c}2,597 \\
2,616 \\
11,208 \\
2,316 \\
1,945 \\
5,696\end{array}$ \\
\hline Média & & 6,73 & 8,47 & 0,362 & 0,125 & 4,396 \\
\hline $\begin{array}{l}\text { T2 } \\
200 \text { ppm. Cu } \\
\text { O ppm. Zn }\end{array}$ & $\begin{array}{l}1 \\
2 \\
3 \\
4 \\
5 \\
6\end{array}$ & $\begin{array}{l}6,68 \\
5,87 \\
7,13 \\
7,93 \\
6,67 \\
6,13\end{array}$ & $\begin{array}{c}9,36 \\
9,17 \\
7,97 \\
10,43 \\
10,37 \\
8,57\end{array}$ & $\begin{array}{l}0,382 \\
0,390 \\
0,257 \\
0,443 \\
0,548 \\
0,398\end{array}$ & $\begin{array}{l}0,198 \\
0,236 \\
0,060 \\
0,179 \\
0,264 \\
0,174\end{array}$ & $\begin{array}{l}2,021 \\
1,653 \\
4,283 \\
2,475 \\
2,076 \\
2,287\end{array}$ \\
\hline Média & & 6,74 & 9,31 & 0,403 & 0,184 & 2,466 \\
\hline $\begin{array}{l}\text { T3 } \\
0 \text { ppm. Cu } \\
2500 \text { ppm. Zn }\end{array}$ & $\begin{array}{l}1 \\
2 \\
3 \\
4 \\
5 \\
6\end{array}$ & $\begin{array}{l}6,75 \\
5,83 \\
7,13 \\
7,93 \\
6,60 \\
6,07\end{array}$ & $\begin{array}{c}10,43 \\
10,20 \\
9,50 \\
13,30 \\
12,23 \\
10,10\end{array}$ & $\begin{array}{l}0,520 \\
0,481 \\
0,364 \\
0,571 \\
0,633 \\
0,562\end{array}$ & $\begin{array}{l}0,263 \\
0,312 \\
0,169 \\
0,386 \\
0,402 \\
0,288\end{array}$ & $\begin{array}{l}1,977 \\
1,542 \\
2,154 \\
1,479 \\
1,575 \\
1,951\end{array}$ \\
\hline Média & & 6,72 & 10,96 & 0,522 & 0,303 & 1,780 \\
\hline $\begin{array}{l}\text { T4 } \\
200 \mathrm{ppm} . \mathrm{Cu} \\
2500 \mathrm{ppm} \mathrm{Zn}\end{array}$ & $\begin{array}{l}1 \\
2 \\
3 \\
4 \\
5 \\
6\end{array}$ & $\begin{array}{l}6,85 \\
5,87 \\
7,13 \\
7,93 \\
6,60 \\
6,13\end{array}$ & $\begin{array}{c}9,83 \\
8,80 \\
7,67 \\
12,40 \\
10,97 \\
9,23\end{array}$ & $\begin{array}{l}0,418 \\
0,407 \\
0,214 \\
0,545 \\
0,510 \\
0,493\end{array}$ & $\begin{array}{l}0,213 \\
0,210 \\
0,038 \\
0,319 \\
0,312 \\
0,221\end{array}$ & $\begin{array}{l}1,962 \\
1,938 \\
5,632 \\
1,708 \\
1,635 \\
2,231\end{array}$ \\
\hline Média & & 6,75 & 9,82 & 0,431 & 0,219 & 2,518 \\
\hline $\begin{array}{l}\text { T5 } \\
100 \text { ppm.Cu } \\
1200 \text { ppm. Zn }\end{array}$ & $\begin{array}{l}1 \\
2 \\
3 \\
4 \\
5 \\
6\end{array}$ & $\begin{array}{l}6,73 \\
5,87 \\
7,13 \\
7,90 \\
6,60 \\
6,07\end{array}$ & $\begin{array}{c}10,70 \\
9,20 \\
9,10 \\
11,43 \\
10,97 \\
7,97\end{array}$ & $\begin{array}{l}0,454 \\
0,431 \\
0,352 \\
0,502 \\
0,600 \\
0,433\end{array}$ & $\begin{array}{l}0,284 \\
0,238 \\
0,140 \\
0,252 \\
0,312 \\
0,136\end{array}$ & $\begin{array}{l}1,599 \\
1,811 \\
2,514 \\
1,992 \\
1,923 \\
3,184\end{array}$ \\
\hline Média & & 6,72 & 9,90 & 0,462 & 0,227 & 2,171 \\
\hline
\end{tabular}


Tabela A2 - Resultados da performance dos leitōes suplementados com altos niveis de Cu e Zn na ração (semanas 1 a 4).

\begin{tabular}{|c|c|c|c|c|c|c|}
\hline $\begin{array}{l}\text { Niveis de } \mathrm{Cu} \text { e } \mathrm{Zn} \\
\text { na raçäo }\end{array}$ & Bloco & $\mathrm{PMI}^{*}$ & PMF* & $\mathrm{CDR}^{*}$ & GDP* $^{*}$ & $\mathrm{CA}^{*}$ \\
\hline $\begin{array}{l}\text { T1 } \\
0 \text { ppm }\end{array}$ & $\begin{array}{l}1 \\
2 \\
3 \\
4 \\
5 \\
6\end{array}$ & $\begin{array}{l}6,73 \\
5,87 \\
7,07 \\
7,90 \\
6,67 \\
6,13\end{array}$ & $\begin{array}{l}15,13 \\
13,43 \\
13,70 \\
18,97 \\
18,20 \\
14,10\end{array}$ & $\begin{array}{l}0,604 \\
0,579 \\
0,500 \\
0,813 \\
0,796 \\
0,669\end{array}$ & $\begin{array}{l}0,300 \\
0,270 \\
0,237 \\
0,395 \\
0,412 \\
0,285\end{array}$ & $\begin{array}{l}2,013 \\
2,144 \\
2,110 \\
2,058 \\
1,932 \\
2,347\end{array}$ \\
\hline Média & & 6,73 & 15,59 & 0,660 & 0,317 & 2,101 \\
\hline $\begin{array}{l}\text { T2 } \\
200 \text { ppm. Cu } \\
0 \text { ppm. Zn }\end{array}$ & $\begin{array}{l}1 \\
2 \\
3 \\
4 \\
5 \\
6\end{array}$ & $\begin{array}{l}6,68 \\
5,87 \\
7,13 \\
7,93 \\
6,67 \\
6,13\end{array}$ & $\begin{array}{l}14,60 \\
15,93 \\
12,63 \\
15,30 \\
16,07 \\
13,30\end{array}$ & $\begin{array}{l}0,567 \\
0,646 \\
0,436 \\
0,615 \\
0,820 \\
0,630\end{array}$ & $\begin{array}{l}0,283 \\
0,360 \\
0,196 \\
0,264 \\
0,336 \\
0,256\end{array}$ & $\begin{array}{l}2,004 \\
1,794 \\
2,224 \\
2,330 \\
2,440 \\
2,461\end{array}$ \\
\hline Média & & 6,74 & 14,64 & 0,619 & 0,283 & 2,209 \\
\hline $\begin{array}{l}\text { T3 } \\
0 \text { ppm. Cu } \\
2500 \text { ppm. } \mathrm{Zn}\end{array}$ & $\begin{array}{l}1 \\
2 \\
3 \\
4 \\
5 \\
6\end{array}$ & $\begin{array}{l}6,75 \\
5,83 \\
7,13 \\
7,93 \\
6,60 \\
6,07\end{array}$ & $\begin{array}{l}17,55 \\
18,70 \\
17,77 \\
23,17 \\
22,03 \\
18,47\end{array}$ & $\begin{array}{l}0,764 \\
0,871 \\
0,773 \\
0,981 \\
1,029 \\
1,021\end{array}$ & $\begin{array}{l}0,386 \\
0,460 \\
0,380 \\
0,544 \\
0,551 \\
0,443\end{array}$ & $\begin{array}{l}1,979 \\
1,893 \\
2,034 \\
1,803 \\
1,868 \\
2,305\end{array}$ \\
\hline Média & & 6,72 & 19,62 & 0,907 & 0,461 & 1,980 \\
\hline $\begin{array}{l}\text { T4 } \\
200 \mathrm{ppm} . \mathrm{Cu} \\
2500 \mathrm{ppm} \mathrm{Zn}\end{array}$ & $\begin{array}{l}1 \\
2 \\
3 \\
4 \\
5 \\
6\end{array}$ & $\begin{array}{l}6,85 \\
5,87 \\
7,13 \\
7,93 \\
6,60 \\
6,13\end{array}$ & $\begin{array}{l}13,33 \\
16,87 \\
10,27 \\
21,03 \\
19,30 \\
17,13\end{array}$ & $\begin{array}{l}0,522 \\
0,748 \\
0,345 \\
0,849 \\
0,830 \\
0,901\end{array}$ & $\begin{array}{l}0,231 \\
0,393 \\
0,112 \\
0,468 \\
0,454 \\
0,393\end{array}$ & $\begin{array}{l}2,260 \\
1,903 \\
3,080 \\
1,814 \\
1,828 \\
2,293\end{array}$ \\
\hline Média & & 6,75 & 16,32 & 0,699 & 0,342 & 2,196 \\
\hline $\begin{array}{l}\text { T5 } \\
100 \text { ppm.Cu } \\
1200 \text { ppm. } \mathrm{Zn}\end{array}$ & $\begin{array}{l}1 \\
2 \\
3 \\
4 \\
5 \\
6\end{array}$ & $\begin{array}{l}6,73 \\
5,87 \\
7,13 \\
7,90 \\
6,60 \\
6,07\end{array}$ & $\begin{array}{l}17,65 \\
17,60 \\
16,10 \\
21,13 \\
19,80 \\
14,97\end{array}$ & $\begin{array}{l}0,742 \\
0,777 \\
0,524 \\
0,923 \\
0,890 \\
0,798\end{array}$ & $\begin{array}{l}0,390 \\
0,419 \\
0,320 \\
0,473 \\
0,471 \\
0,318\end{array}$ & $\begin{array}{l}1,903 \\
1,854 \\
1,638 \\
1,951 \\
1,890 \\
2,509\end{array}$ \\
\hline Média & & 6,72 & 17,88 & 0,776 & 0,399 & 1,958 \\
\hline
\end{tabular}


Tabela A3 - Análises estatísticas dos dados de ganho diário médio de peso (GDP, g) dos leitões suplementados com altos niveis de Cu e $Z n$ na ração (Semanas 1 e 2 e semanas 1 a 4).

STATISTICAL ANALYSIS SYSTEM (SAS)

General Linear Models Procedure

\section{Semanas 1e 2}

Dependent Variable: GDP

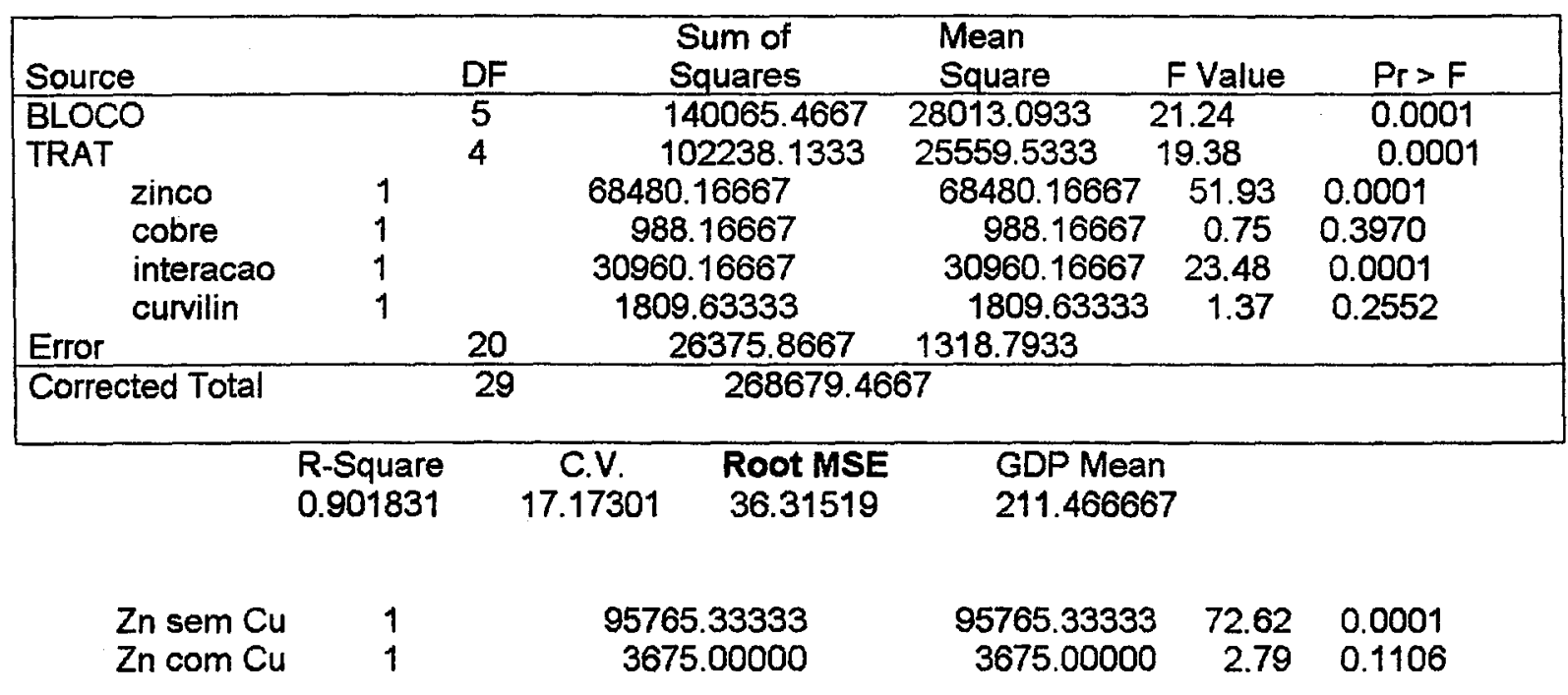

\section{Semanas 1 a 4}

Dependent Variable: GDP

\begin{tabular}{|c|c|c|c|c|c|c|}
\hline \multicolumn{2}{|l|}{ Source } & \multicolumn{2}{|c|}{$\begin{array}{l}\text { Sum of } \\
\text { Squares }\end{array}$} & $\begin{array}{l}\text { Mean } \\
\text { Square }\end{array}$ & F Value & $\operatorname{Pr}>F$ \\
\hline $\begin{array}{l}\text { BLOCO } \\
\text { TRAT } \\
\quad \text { zinco } \\
\text { cobre } \\
\text { interacao } \\
\quad \text { curvilin } \\
\text { Error }\end{array}$ & $\begin{array}{ll} & 5 \\
& 4 \\
1 & \\
1 & \\
1 & \\
1 & \\
& 20\end{array}$ & $\begin{array}{r}134 \\
1190 \\
62118.3 \\
35037 . \\
10795 . \\
11116.8 \\
583\end{array}$ & $\begin{array}{l}333.2000 \\
67.3333 \\
7500 \\
14167 \\
14167 \\
7500 \\
75.4667\end{array}$ & $\begin{array}{c}26866.6400 \\
29766.8333 \\
62118.2237500 \\
35037.04167 \\
10795.04167 \\
11116.87500 \\
2918.7733\end{array}$ & $\begin{array}{r}9.20 \\
10.20 \\
21.28 \\
12.00 \\
3.70 \\
3.81\end{array}$ & $\begin{array}{l}0.0001 \\
0.0001 \\
0.000222 \\
0.0024 \\
0.0688 \\
0.0651\end{array}$ \\
\hline Corrected Total & 29 & 311 & 776.0000 & & & \\
\hline \multicolumn{2}{|c|}{$\begin{array}{c}\text { R-Square } \\
0.812765\end{array}$} & $\begin{array}{l}\text { C.V. } \\
15.00713\end{array}$ & $\begin{array}{l}\text { Root MSE } \\
54.02567\end{array}$ & \multicolumn{2}{|c|}{$\begin{array}{l}\text { GDP Mean } \\
360.000000\end{array}$} & \\
\hline $\begin{array}{l}\mathrm{Zn} \operatorname{sem} \mathrm{Cu} \\
\mathrm{Zn} \operatorname{com} \mathrm{Cu}\end{array}$ & $\begin{array}{l}1 \\
1\end{array}$ & $\begin{array}{l}62352 . \\
10561 .\end{array}$ & $\begin{array}{l}8333 \\
13333\end{array}$ & $\begin{array}{l}62352.08333 \\
10561.33333\end{array}$ & $\begin{array}{r}21.36 \\
3.62\end{array}$ & $\begin{array}{l}0.0002 \\
0.0716\end{array}$ \\
\hline
\end{tabular}


Tabela A4 - Análises estatísticas dos dados de consumo diário médio de ração (CDR, g) dos leitões suplementados com altos niveis de Cu e $Z n$ na ração (Semanas 1 e 2 e semanas 1 a 4 ).

STATISTICAL ANALYSIS SYSTEM (SAS)

General Linear Models Procedure

Dependent Variable: CDR

\section{Semanas 1 e 2}

\begin{tabular}{|lcccccc|}
\hline Source & & DF & $\begin{array}{c}\text { Sum of } \\
\text { Squares }\end{array}$ & $\begin{array}{l}\text { Mean } \\
\text { Square }\end{array}$ & F Value & $\operatorname{Pr}>F$ \\
\hline BLOCO & & 5 & 192047.0667 & 38409.4133 & 29.90 & 0.0001 \\
TRAT & & 4 & 88063.8000 & 22015.9500 & 17.14 & 0.0001 \\
$\quad$ zinco & 1 & & 53204.16667 & 53204.16667 & 41.42 & 0.0001 \\
$\quad$ cobre & 1 & & 3601.50000 & 3601.50000 & 2.80 & 0.1096 \\
$\quad$ interacao & 1 & & 26136.00000 & 26136.00000 & 20.35 & 0.0002 \\
$\quad$ curvilin & 1 & & 5122.13333 & 5122.13333 & 3.99 & 0.0596 \\
Error & & 20 & 25690.6000 & 1284.5300 & & \\
\hline Corrected Total & & & & & & \\
\end{tabular}

$\begin{array}{cccc}\text { R-Square } & \text { C.V. } & \text { Root MSE } & \text { CDR Mean } \\ 0.915989 & 8.222776 & 35.84034 & 435.866667\end{array}$

Zn sem Cu 1

$\mathrm{Zn} \mathrm{com} \mathrm{Cu} 1$
76960.08333

2380.08333
76960.08333

2380.08333
59.91

1.85
0.0001

0.1886

\section{Semanas 1 a 4}

Dependent Variable: CDR

\begin{tabular}{|c|c|c|c|c|c|c|}
\hline Source & DF & \multicolumn{2}{|c|}{$\begin{array}{l}\text { Sum of } \\
\text { Squares }\end{array}$} & $\begin{array}{l}\text { Mean } \\
\text { Square }\end{array}$ & F Value & $\operatorname{Pr}>F$ \\
\hline 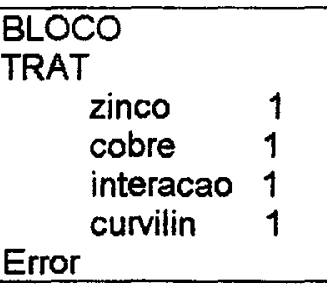 & $\begin{array}{l}5 \\
4 \\
\\
\\
20\end{array}$ & \multirow{2}{*}{\multicolumn{2}{|c|}{$\begin{array}{c}457145.6000 \\
307713.3333 \\
159740.1667 \\
92504.1667 \\
41168.1667 \\
14300.8333 \\
110429.0667 \\
875288.0000\end{array}$}} & $\begin{array}{c}91429.1200 \\
76928.3333 \\
159740.1667 \\
92504.1667 \\
41168.1667 \\
14300.8333 \\
5521.4533 \\
\end{array}$ & $\begin{array}{c}16.56 \\
13.93 \\
28.93 \\
16.75 \\
7.46 \\
2.59\end{array}$ & $\begin{array}{c}0.0001 \\
0.0001 \\
0.0001 \\
0.0006 \\
0.0129 \\
0.1232\end{array}$ \\
\hline Corrected Total & 29 & & & & & \\
\hline $\begin{array}{l}\text { R-Square } \\
0.873837\end{array}$ & & $\begin{array}{c}\text { C.V. } \\
10.15116\end{array}$ & $\begin{array}{l}\text { Root MSE } \\
74.30648\end{array}$ & $\begin{array}{l}\text { CDR Mean } \\
732.000000\end{array}$ & & \\
\hline $\begin{array}{ll}Z n \text { sem } \mathrm{Cu} & 1 \\
\mathrm{Zn} \operatorname{com} \mathrm{Cu} & 1\end{array}$ & & $\begin{array}{r}181548 \\
19360\end{array}$ & $\begin{array}{l}300 \\
333\end{array}$ & $\begin{array}{r}181548.0000 \\
19360.3333\end{array}$ & $\begin{array}{r}32.88 \\
3.51\end{array}$ & $\begin{array}{l}0.0001 \\
0.0758\end{array}$ \\
\hline
\end{tabular}


Tabela A5 - Análises estatísticas dos dados de conversão alimentar média (CA) dos leitões suplementados com altos níveis de $\mathrm{Cu}$ e $\mathrm{Zn}$ na ração (Semanas 1 e 2 e semanas 1 a 4).

STATISTICAL ANALYSIS SYSTEM (SAS)

General Linear Models Procedure

Semanas 1 e 2

Dependent Variable: CA

\begin{tabular}{|c|c|c|c|c|c|}
\hline Source & DF & $\begin{array}{l}\text { Sum of } \\
\text { Squares }\end{array}$ & $\begin{array}{l}\text { Mean } \\
\text { Square }\end{array}$ & F Value & $\mathrm{Pr}>\mathrm{F}$ \\
\hline $\begin{array}{l}\text { BLOCO } \\
\text { TRAT }\end{array}$ & 5 & 3.38877852 & $\begin{array}{l}0.67775570 \\
059779851\end{array}$ & $\begin{array}{l}3.51 \\
310\end{array}$ & 0.0231 \\
\hline zinco & 1 & 2.07443405 & 2.07443405 & 10.75 & 0.0044 \\
\hline cobre & 1 & 0.01388641 & 0.01388641 & 0.07 & 0.7917 \\
\hline interacao & 1 & 0.26436736 & 0.26436736 & 1.37 & 0.2579 \\
\hline curvilin & 1 & 0.02475667 & 0.02475667 & 0.13 & 0.7246 \\
\hline Error & 17 & 3.27921264 & 0.19289486 & & \\
\hline Corrected Total & 26 & 9.05918519 & & & \\
\hline $\begin{array}{l}\text { R-Square } \\
0.638023\end{array}$ & $\begin{array}{c}\text { C.V. } \\
20.62680\end{array}$ & $\begin{array}{c}\text { Root MSE } \\
0.439198\end{array}$ & $\begin{array}{l}\text { CA Mean } \\
2.12925926\end{array}$ & & \\
\hline $\begin{array}{l}\text { Zn sem Cu } \\
\text { Zn com Cu }\end{array}$ & $\begin{array}{l}1 \\
1\end{array}$ & $\begin{array}{l}1.75129150 \\
0.43800395\end{array}$ & $\begin{array}{l}1.75129150 \\
0.43800395\end{array}$ & $\begin{array}{l}9.08 \\
2.27\end{array}$ & $\begin{array}{l}0.0078 \\
0.1502\end{array}$ \\
\hline
\end{tabular}

\section{Semanas 1 a 4}

Dependent Variable:CA

\begin{tabular}{|c|c|c|c|c|c|c|}
\hline Source & & DF & $\begin{array}{l}\text { Sum of } \\
\text { Squares }\end{array}$ & $\begin{array}{l}\text { Mean } \\
\text { Square }\end{array}$ & F Value & $P r>F$ \\
\hline $\begin{array}{l}\text { BLOCO } \\
\text { TRAT } \\
\text { zinco } \\
\text { cobre } \\
\text { interacao } \\
\text { curvilin } \\
\text { Error }\end{array}$ & $\begin{array}{l}1 \\
1 \\
1 \\
1\end{array}$ & $\begin{array}{l}5 \\
4\end{array}$ & $\begin{array}{c}0.76870667 \\
0.32944667 \\
0.02600417 \\
0.15843750 \\
0.01760417 \\
0.12740083 \\
1.43819333\end{array}$ & $\begin{array}{c}0.15374133 \\
0.08236167 \\
0.02600417 \\
0.15843750 \\
0.01760417 \\
0.12740083 \\
0.07190967\end{array}$ & $\begin{array}{l}2.14 \\
1.15 \\
0.36 \\
2.20 \\
0.24 \\
1.77\end{array}$ & $\begin{array}{l}0.1026 \\
0.3641 \\
0.5544 \\
0.1533 \\
0.6261 \\
0.1981\end{array}$ \\
\hline Error & & 20 & 1.43819333 & 0.07190967 & & \\
\hline
\end{tabular}

$\begin{array}{lccl}\text { R-Square } & \text { C.V. } & \text { Root MSE } & \text { CA Mean } \\ 0.432967 & 12.83880 & 0.268160 & 2.08866667\end{array}$

Zn sem Cu 1 
Tabela A6 - Resultados dos componentes sanguineos (hematócrito e hemoglobina) e plasmáticos (proteína total, albumina, globulina, relação albumina/globulina $e$ uréia) dos leitões suplementados com altos niveis de $\mathrm{Cu}$ e $\mathrm{Zn}$ na ração.

\begin{tabular}{|c|c|c|c|c|c|c|c|c|}
\hline \multirow[b]{2}{*}{$\begin{array}{l}\text { Tratamentos } \\
\text { (Niveis de Cu e Zn) }\end{array}$} & \multirow[b]{2}{*}{ Blocos } & \multicolumn{2}{|c|}{ Sangue ${ }^{\mathrm{a}}$} & \multicolumn{2}{|c|}{$P$} & \multirow{2}{*}{$\begin{array}{cc}a & s \\
& \text { Glo, } \\
& \text { g/dl } \\
\end{array}$} & \multirow{2}{*}{$\begin{array}{l}\frac{m}{m} a^{D} \\
\text { Relação } \\
\text { Alb/Glo }\end{array}$} & \multirow[b]{2}{*}{$\begin{array}{l}\text { Ur, } \\
\mathrm{mg} / \mathrm{dl}\end{array}$} \\
\hline & & $\begin{array}{c}\mathrm{Ht}_{1}^{\mathrm{c}} \\
\%\end{array}$ & $\begin{array}{l}\mathrm{Hb} \\
\mathrm{g} / \mathrm{dl}\end{array}$ & $\begin{array}{l}\mathrm{Pt}{ }^{\mathrm{c}} \\
\mathrm{g} / \mathrm{dl}\end{array}$ & $\begin{array}{l}\text { Alb, } \\
\text { g/d }\end{array}$ & & & \\
\hline $\begin{array}{l}\text { T1 } \\
0 \text { ppm }\end{array}$ & $\begin{array}{c}1 \\
2 \\
3 \\
4 \\
5 \\
6 \\
\text { Média }\end{array}$ & $\begin{array}{c}39,0 \\
33,0 \\
34,5 \\
39,5 \\
34,0 \\
33,5 \\
35,58\end{array}$ & $\begin{array}{l}12,00 \\
10,40 \\
10,20 \\
12,15 \\
10,95 \\
10,70 \\
11,07\end{array}$ & $\begin{array}{l}5,5 \\
5,6 \\
5,4 \\
5,6 \\
5,6 \\
5,4 \\
5,52\end{array}$ & $\begin{array}{l}3,00 \\
3,30 \\
2,60 \\
3,50 \\
3,20 \\
3,30 \\
3,15\end{array}$ & $\begin{array}{c}2,5 \\
2,3 \\
2,8 \\
2,1 \\
2,4 \\
2,1 \\
2,37\end{array}$ & $\begin{array}{l}1,20 \\
1,43 \\
0,93 \\
1,67 \\
1,33 \\
1,57 \\
1,36\end{array}$ & $\begin{array}{c}- \\
37,0 \\
28,0 \\
30,0 \\
20,0 \\
21,0 \\
24,17\end{array}$ \\
\hline $\begin{array}{l}\text { T2 } \\
200 \text { ppm. } \mathrm{Cu} \\
\quad 0 \text { ppm. } \mathrm{Zn}\end{array}$ & $\begin{array}{c}1 \\
2 \\
3 \\
4 \\
5 \\
6 \\
\text { Média }\end{array}$ & $\begin{array}{c}31,5 \\
34,5 \\
24,5 \\
34,5 \\
34,5 \\
32,0 \\
31,92\end{array}$ & $\begin{array}{c}9,65 \\
10,10 \\
7,95 \\
10,85 \\
10,70 \\
10,25 \\
9,92\end{array}$ & $\begin{array}{c}5,4 \\
5,0 \\
5,4 \\
5,7 \\
6,0 \\
5,8 \\
5,55\end{array}$ & $\begin{array}{l}3,10 \\
3,20 \\
2,90 \\
3,50 \\
3,70 \\
3,50 \\
3,32\end{array}$ & $\begin{array}{l}2,3 \\
1,8 \\
2,5 \\
2,2 \\
2,3 \\
2,3 \\
2,23\end{array}$ & $\begin{array}{l}1,35 \\
1,78 \\
1,16 \\
1,59 \\
1,61 \\
1,52 \\
1,50\end{array}$ & $\begin{array}{l}33,0 \\
20,0 \\
41,0 \\
31,0 \\
53,0 \\
26,0 \\
34,0\end{array}$ \\
\hline $\begin{array}{l}\text { T3 } \\
0 \text { ppm. Cu } \\
2500 \text { ppm. Zn }\end{array}$ & $\begin{array}{c}1 \\
2 \\
3 \\
4 \\
5 \\
6 \\
\text { Média }\end{array}$ & $\begin{array}{c}35,0 \\
36,0 \\
35,0 \\
40,0 \\
37,5 \\
38,0 \\
36,92\end{array}$ & $\begin{array}{l}11,45 \\
11,35 \\
10,55 \\
12,00 \\
12,00 \\
11,95 \\
11,55\end{array}$ & $\begin{array}{c}5,2 \\
5,5 \\
5,6 \\
5,5 \\
5,4 \\
5,4 \\
5,43\end{array}$ & $\begin{array}{l}2,70 \\
2,90 \\
3,00 \\
3,30 \\
3,30 \\
3,30 \\
3,08\end{array}$ & $\begin{array}{l}2,5 \\
2,6 \\
2,6 \\
2,2 \\
2,1 \\
2,1 \\
2,35\end{array}$ & $\begin{array}{l}1,08 \\
1,12 \\
1,15 \\
1,50 \\
1,57 \\
1,57 \\
1,33\end{array}$ & $\begin{array}{c}- \\
43,0 \\
28,0 \\
39,0 \\
34,0 \\
25,0 \\
30,00\end{array}$ \\
\hline $\begin{array}{l}T 4 \\
200 \text { ppm. Cu } \\
2500 \text { ppm. } Z n\end{array}$ & $\begin{array}{c}1 \\
2 \\
3 \\
4 \\
5 \\
6 \\
\text { Média }\end{array}$ & $\begin{array}{c}29,5 \\
35,5 \\
22,0 \\
36,5 \\
35,0 \\
35,5 \\
32,33\end{array}$ & $\begin{array}{c}9,50 \\
11,20 \\
7,30 \\
10,80 \\
10,90 \\
11,55 \\
10,21\end{array}$ & $\begin{array}{c}4,8 \\
5,3 \\
4,9 \\
5,2 \\
5,2 \\
4,9 \\
5,05\end{array}$ & $\begin{array}{l}2,20 \\
2,90 \\
2,20 \\
2,90 \\
2,80 \\
2,90 \\
2,65\end{array}$ & $\begin{array}{l}2,6 \\
2,4 \\
2,7 \\
2,3 \\
2,4 \\
2,0 \\
2,40\end{array}$ & $\begin{array}{l}0,85 \\
1,21 \\
0,81 \\
1,26 \\
1,17 \\
1,45 \\
1,13\end{array}$ & $\begin{array}{c}34,0 \\
24,0 \\
50,0 \\
27,0 \\
33,0 \\
22,0 \\
31,67\end{array}$ \\
\hline $\begin{array}{l}\text { T5 } \\
100 \mathrm{ppm} . \mathrm{Cu} \\
1250 \mathrm{ppm} . \mathrm{Zn}\end{array}$ & $\begin{array}{c}1 \\
2 \\
3 \\
4 \\
5 \\
6 \\
\text { Média } \\
\end{array}$ & $\begin{array}{c}34,5 \\
36,0 \\
29,0 \\
38,0 \\
35,5 \\
36,0 \\
34,83 \\
\end{array}$ & $\begin{array}{c}11,25 \\
11,00 \\
9,00 \\
11,50 \\
10,95 \\
11,25 \\
10,83 \\
\end{array}$ & $\begin{array}{c}5,6 \\
5,4 \\
5,1 \\
5,3 \\
5,6 \\
5,3 \\
5,38 \\
\end{array}$ & $\begin{array}{l}3,10 \\
3,40 \\
2,50 \\
3,60 \\
3,20 \\
3,40 \\
3,20 \\
\end{array}$ & $\begin{array}{c}2,5 \\
2,0 \\
2,6 \\
1,7 \\
2,4 \\
1,9 \\
2,18 \\
\end{array}$ & $\begin{array}{l}1,24 \\
1,70 \\
0,96 \\
2,12 \\
1,33 \\
1,79 \\
1,52\end{array}$ & $\begin{array}{c}32,0 \\
24,0 \\
30,0 \\
31,0 \\
31,0 \\
26,0 \\
29,00\end{array}$ \\
\hline
\end{tabular}

a Valores individuais representam as médias de dois animais de cada baia.

b Valores individuais correspondem a amostras compostas de plasma de dois animais de cada baia.

c Componentes sanguineos: $\mathrm{Ht}=$ hematócrito; $\mathrm{Hb}=$ hemoglobina e componentes plasmáticos: $\mathrm{Pt}=$ proteina total; $\mathrm{Alb}=$ albumina; $\mathrm{Glo}=$ globulina; Relação Alb/Glo $=$ relação albumina / globulina; Ur = uréia. 
Tabela A7 - Análises estatísticas dos dados de hematócrito $(\mathrm{Ht}, \%)$ e de hemoglobina $(\mathrm{Hg} / \mathrm{dl})$ dos leitões suplementados com altos niveis de Cu e $Z$ n na ração.

STATISTICAL ANALYSIS SYSTEM (SAS)

General Linear Models Procedure

Hematócrito (Ht)

Dependent Variable: HT

\begin{tabular}{|c|c|c|c|c|c|}
\hline Source & DF & $\begin{array}{l}\text { Sum of } \\
\text { Squares }\end{array}$ & $\begin{array}{l}\text { Mean } \\
\text { Square }\end{array}$ & F Value & $\operatorname{Pr}>\mathrm{F}$ \\
\hline BLOCO & 5 & 208.9416667 & 41.7883333 & 6.24 & 0.0012 \\
\hline TRAT & 4 & 109.9500000 & 27.4875000 & 4.11 & 0.0137 \\
\hline zinco & 1 & 4.5937500 & 4.5937500 & 0.69 & 0.4172 \\
\hline cobre & 1 & 102.0937500 & 102.0937500 & 15.25 & 0.0009 \\
\hline interacao & 1 & 1.2604167 & 1.2604167 & 0.19 & 0.6690 \\
\hline curvilin & 1 & 2.0020833 & 2.0020833 & 0.30 & 0.5905 \\
\hline Error & 20 & 133.8500000 & 6.6925000 & & \\
\hline Corrected Total & 29 & 452.7416667 & & & \\
\hline
\end{tabular}

$\begin{array}{cccl}\text { R-Square } & \text { C.V. } & \text { Root MSE } & \text { HT Mean } \\ 0.704357 & 7.538572 & 2.586987 & 34.3166667\end{array}$

$\begin{array}{llllll}\mathrm{Zn} \mathrm{sem} \mathrm{Cu} & 1 & 5.3333333 & 5.3333333 & 0.80 & 0.3826 \\ \mathrm{Zn} \text { com Cu} & 1 & 0.5208333 & 0.5208333 & 0.08 & 0.7831\end{array}$

\section{Hemoglobina $(\mathrm{Hg})$}

Dependent Variable: HG

\begin{tabular}{|c|c|c|c|c|c|c|}
\hline Source & & DF & $\begin{array}{l}\text { Sum of } \\
\text { Squares }\end{array}$ & $\begin{array}{l}\text { Mean } \\
\text { Square }\end{array}$ & $F$ Value & $\operatorname{Pr}>\mathrm{F}$ \\
\hline $\begin{array}{l}\text { BLOCO } \\
\text { TRAT } \\
\quad \text { zinco } \\
\text { cobre } \\
\text { interacao } \\
\quad \text { curvilin } \\
\text { Error } \\
\end{array}$ & $\begin{array}{l}1 \\
1 \\
1 \\
1\end{array}$ & $\begin{array}{l}5 \\
4\end{array}$ & $\begin{array}{c}19.19046667 \\
10.29864667 \\
0.88550417 \\
9.26283750 \\
0.05900417 \\
0.09130083 \\
8.12703333 \\
\end{array}$ & $\begin{array}{c}3.83809333 \\
2.57466167 \\
0.88550417 \\
9.26283750 \\
0.05900417 \\
0.09130083 \\
0.40635167 \\
\end{array}$ & $\begin{array}{c}9.45 \\
6.34 \\
2.18 \\
22.80 \\
0.15 \\
0.22\end{array}$ & $\begin{array}{l}0.0001 \\
0.0018 \\
0.1555 \\
0.0001 \\
0.7072 \\
0.6406\end{array}$ \\
\hline Corrected Total & & 29 & 37.61614667 & & & \\
\hline \multicolumn{2}{|c|}{$\begin{array}{l}\text { R-Square } \\
0.783948\end{array}$} & $\begin{array}{c}\text { C.V. } \\
5.949389\end{array}$ & $\begin{array}{l}\text { Root MSE } \\
0.637457\end{array}$ & $\begin{array}{c}\text { HG Mean } \\
10.7146667\end{array}$ & & \\
\hline $\begin{array}{l}\mathrm{Zn} \text { sem } \mathrm{Cu} \\
\mathrm{Zn} \mathrm{com} \mathrm{Cu}\end{array}$ & $\begin{array}{l}1 \\
1\end{array}$ & & $\begin{array}{l}0.70083333 \\
0.24367500\end{array}$ & $\begin{array}{l}0.70083333 \\
0.24367500\end{array}$ & $\begin{array}{l}1.72 \\
0.60\end{array}$ & $\begin{array}{l}0.2040 \\
0.4478\end{array}$ \\
\hline
\end{tabular}


Tabela A8 - Análises estatísticas dos dados de proteina total $(\mathrm{Pt}, \mathrm{g} / \mathrm{dl})$ e de albumina (Alb, g/dl) dos leitões suplementados com altos níveis de $\mathrm{Cu}$ e $\mathrm{Zn}$ na ração.

STATISTICAL ANALYSIS SYSTEM (SAS)

General Linear Models Procedure

Proteina total (Pt, g/dl)

Dependent Variable: Pt

\begin{tabular}{|lcccccc|}
\hline Source & DF & $\begin{array}{l}\text { Sum of } \\
\text { Squares }\end{array}$ & $\begin{array}{l}\text { Mean } \\
\text { Square }\end{array}$ & F Value & Pr $>F$ \\
\hline BLOCO & 5 & 0.278666667 & 0.05573333 & 1.24 & 0.3290 \\
TRAT & & 4 & 0.95466667 & 0.23866667 & 5.30 & 0.0045 \\
zinco & 1 & & 0.51041667 & 0.51041667 & 11.33 & 0.0031 \\
cobre & 1 & & 0.18375000 & 0.18375000 & 4.08 & 0.0571 \\
interacao & 1 & & 0.26041667 & 0.26041667 & 5.78 & 0.0260 \\
curvilin & 1 & & 0.00008333 & 0.00008333 & 0.00 & 0.9661 \\
Error & 20 & 0.90133333 & 0.04506667 & & \\
\hline Corrected Total & 29 & 2.13466667 & & & \\
\hline
\end{tabular}

$\begin{array}{ccrc}\text { R-Square } & \text { C.V. } & \text { Root MSE } & \text { PROT Mean } \\ 0.577764 & 3.941011 & 0.212289 & 5.38666667\end{array}$

$\begin{array}{llllll}\mathrm{Zn} \mathrm{sem} \mathrm{Cu} & 1 & 0.02083333 & 0.02083333 & 0.46 & 0.5044 \\ \mathrm{Zn} \mathrm{com} \mathrm{Cu} & 1 & 0.75000000 & 0.75000000 & 16.64 & 0.0006\end{array}$

\section{Albumina (Alb,g/d)}

Dependent Variable: Alb

\begin{tabular}{|c|c|c|c|c|c|c|c|}
\hline \multicolumn{2}{|l|}{ Source } & \multicolumn{2}{|l|}{ DF } & $\begin{array}{l}\text { Sum of } \\
\text { Squares }\end{array}$ & $\begin{array}{l}\text { Mean } \\
\text { Square }\end{array}$ & F Value & $\mathrm{Pr}>\mathrm{F}$ \\
\hline $\begin{array}{l}\text { BLOCO } \\
\text { TRAT } \\
\quad \text { zinco } \\
\text { cobre } \\
\text { interacao } \\
\text { curvilin } \\
\text { Error }\end{array}$ & $\begin{array}{l}1 \\
1 \\
1 \\
1\end{array}$ & $\begin{array}{l}5 \\
4\end{array}$ & $\begin{array}{l} \\
0.80 \\
0.1 \\
0.5 \\
0.1\end{array}$ & $\begin{array}{l}.04400000 \\
1.56133333 \\
1666667 \\
0666667 \\
1000000 \\
0800000 \\
0.58266667\end{array}$ & $\begin{array}{c}0.40880000 \\
0.39033333 \\
0.80666667 \\
0.10666667 \\
0.54000000 \\
0.10800000 \\
0.02913333\end{array}$ & $\begin{array}{c}14.03 \\
13.40 \\
27.69 \\
3.66 \\
18.54 \\
3.71\end{array}$ & $\begin{array}{c}0.0001 \\
0.0001 \\
0.0001 \\
0.0701 \\
0.0003 \\
0.0685\end{array}$ \\
\hline Corrected Total & & 29 & & 4.18800000 & & & \\
\hline $\begin{array}{l}\text { R-Sq } \\
0.860\end{array}$ & $\begin{array}{l}\text { dare } \\
872\end{array}$ & & $\begin{array}{c}\text { C.V. } \\
5.541717\end{array}$ & $\begin{array}{c}\text { Root MSE } \\
0.170685\end{array}$ & $\begin{array}{c}\text { ALB Mean } \\
3.08000000\end{array}$ & & \\
\hline $\begin{array}{l}\mathrm{Zn} \operatorname{sem} \mathrm{Cl} \\
\mathrm{Zn} \operatorname{com} \mathrm{Cl}\end{array}$ & $\begin{array}{l}1 \\
1\end{array}$ & & & $\begin{array}{l}1333333 \\
3333333\end{array}$ & $\begin{array}{l}0.01333333 \\
1.33333333\end{array}$ & $\begin{array}{c}0.46 \\
45.77\end{array}$ & $\begin{array}{l}0.5065 \\
0.0001\end{array}$ \\
\hline
\end{tabular}


Tabela A9 - Análises estatísticas dos dados de globulina (Glo, g/dl) e da relação Albumina/Globulina (Alb/Glo) dos leitōes suplementados com altos niveis de $\mathrm{Cu}$ e $\mathrm{Zn}$ na ração.

STATISTICAL ANALYSIS SYSTEM (SAS)

General Linear Models Procedure

\section{Globulina (Glo, g/dI)}

Dependent Variable: Glo

\begin{tabular}{|c|c|c|c|c|c|c|c|}
\hline Source & & DF & \multicolumn{2}{|c|}{$\begin{array}{l}\text { Sum of } \\
\text { Squares }\end{array}$} & $\begin{array}{l}\text { Mean } \\
\text { Square }\end{array}$ & F Value & $\operatorname{Pr}>F$ \\
\hline $\begin{array}{ll}\text { BLOCO } \\
\text { TRAT } \\
\\
\begin{array}{l}\text { zinco } \\
\text { cobre } \\
\text { interacao } \\
\text { curvilin }\end{array} \\
\text { Error }\end{array}$ & $\begin{array}{l}1 \\
1 \\
1 \\
1\end{array}$ & $\begin{array}{l}5 \\
4 \\
\\
20\end{array}$ & $\begin{array}{r}1 \\
0 \\
0.033 \\
0.011 \\
0.05 \\
0.11 \\
0 \\
\end{array}$ & $\begin{array}{l}21466667 \\
20866667 \\
75000 \\
41667 \\
41667 \\
08333 \\
7533333 \\
\end{array}$ & $\begin{array}{c}0.24293333 \\
0.05216667 \\
0.03375000 \\
0.01041667 \\
0.05041667 \\
0.11408333 \\
0.03376667 \\
\end{array}$ & $\begin{array}{l}7.19 \\
1.54 \\
1.00 \\
0.31 \\
1.49 \\
3.38\end{array}$ & $\begin{array}{c}0.0005 \\
0.2275 \\
0.3294 \\
0.5848 \\
0.2359 \\
0.0809\end{array}$ \\
\hline \multicolumn{2}{|l|}{ Corrected Total } & 29 & \multicolumn{2}{|c|}{2.09866667} & & & \\
\hline \multicolumn{2}{|c|}{$\begin{array}{l}\text { R-Square } \\
0.678208\end{array}$} & & $\begin{array}{c}\text { C.V. } \\
7.966348\end{array}$ & $\begin{array}{c}\text { Root MSE } \\
0.183757\end{array}$ & \multicolumn{2}{|c|}{$\begin{array}{l}\text { GLO Mean } \\
2.30666667\end{array}$} & \\
\hline $\begin{array}{l}\text { Zn sem } C_{1} \\
Z n \text { com } C_{1}\end{array}$ & $\begin{array}{l}1 \\
1\end{array}$ & & $\begin{array}{l}0.00 \\
0.08\end{array}$ & $\begin{array}{l}83333 \\
333333\end{array}$ & $\begin{array}{l}0.00083333 \\
0.08333333\end{array}$ & $\begin{array}{l}0.02 \\
2.47\end{array}$ & $\begin{array}{l}0.8767 \\
0.1319\end{array}$ \\
\hline
\end{tabular}

\section{Albumina/Globulina (Alb/Glo)}

Dependent Variable: Alb/glo

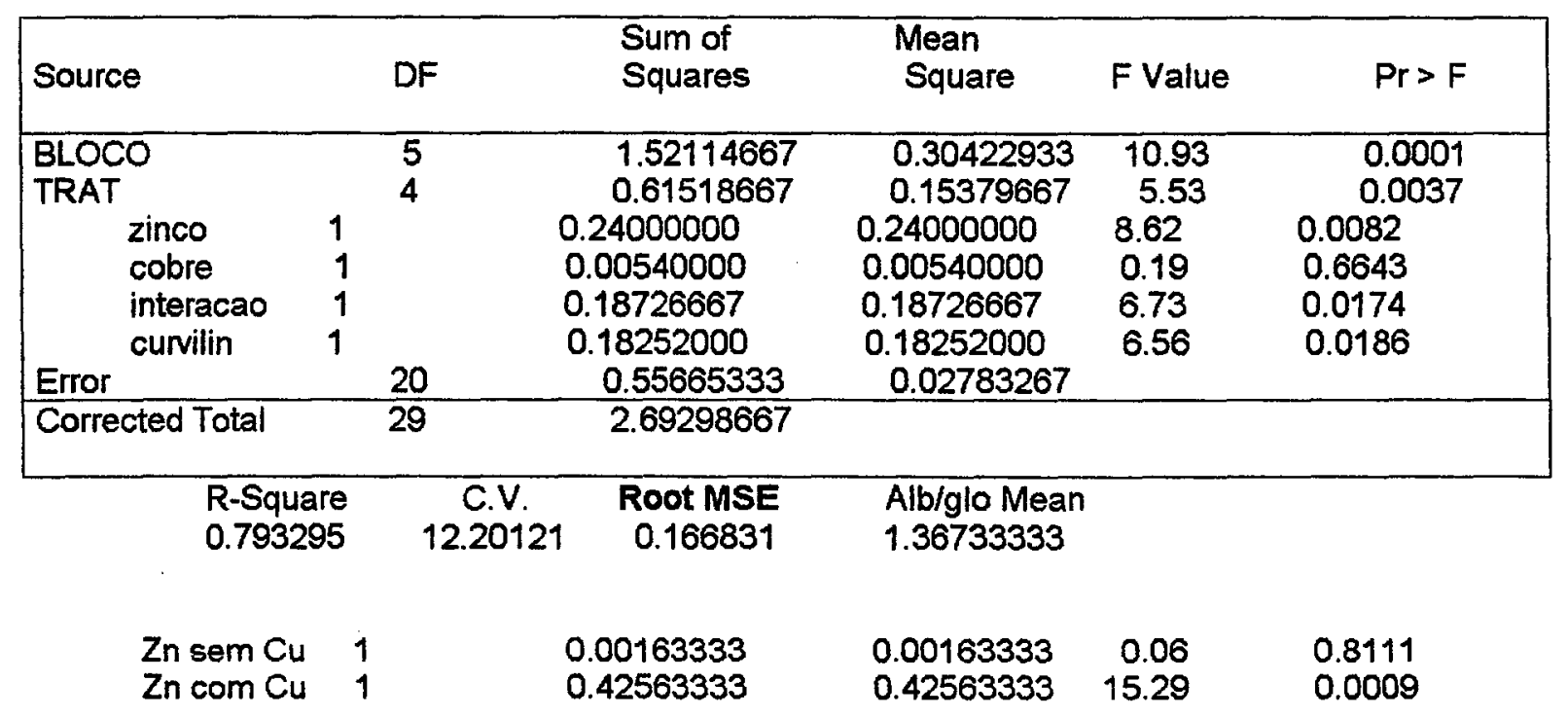


Tabela A10 - Análises estatísticas dos dados de uréia (Ur, mg/di) dos leitões suplementados com altos niveis de $\mathrm{Cu}$ e $\mathrm{Zn}$ na ração.

STATISTICAL ANALYSIS SYSTEM (SAS)

General Linear Models Procedure

\section{Uréia (Ur, mg/dl)}

Dependent Variable: Ur.

\begin{tabular}{|c|c|c|c|c|c|c|}
\hline \multicolumn{2}{|l|}{ Source } & DF & $\begin{array}{l}\text { Sum of } \\
\text { Squares }\end{array}$ & $\begin{array}{l}\text { Mean } \\
\text { Square }\end{array}$ & F Value & $\mathrm{Pr}>\mathrm{F}$ \\
\hline \multicolumn{2}{|l|}{$\begin{array}{l}\text { BLOCO } \\
\text { TRAT }\end{array}$} & $\begin{array}{l}5 \\
4\end{array}$ & $\begin{array}{l}419.9696429 \\
187.9900000\end{array}$ & $\begin{array}{l}83.9939286 \\
46.9975000\end{array}$ & $\begin{array}{l}1.19 \\
0.67\end{array}$ & $\begin{array}{l}0.3524 \\
0.6234\end{array}$ \\
\hline $\begin{array}{l}\text { zinco } \\
\text { cobre } \\
\text { interacao } \\
\text { curvilin }\end{array}$ & $\begin{array}{l}1 \\
1 \\
1 \\
1\end{array}$ & & $\begin{array}{c}25.8034091 \\
22.5003571 \\
106.8034091 \\
37.1807258\end{array}$ & $\begin{array}{c}25.8034091 \\
22.5003571 \\
106.8034091 \\
37.1807258\end{array}$ & $\begin{array}{l}0.37 \\
0.32 \\
1.51 \\
0.53\end{array}$ & $\begin{array}{l}0.5528 \\
0.5791 \\
0.2343 \\
0.4771\end{array}$ \\
\hline Error & & 18 & 1269.2100000 & 70.5116667 & & \\
\hline Corrected Total & & 27 & 1877.1696429 & & & \\
\hline $\begin{array}{r}\text { R-Squ } \\
0.323\end{array}$ & & 26. & $\begin{array}{lc}V . & \text { Root MSE } \\
694 & 8.397123\end{array}$ & $\begin{array}{l}\text { UR Mean } \\
31.1964286\end{array}$ & & \\
\hline
\end{tabular}

$\begin{array}{llrrrr}\text { Zn sem Cu } & 1 & 108.9000000 & 108.9000000 & 1.54 & 0.2299 \\ \text { Zn com Cu } & 1 & 15.1875000 & 15.1875000 & 0.22 & 0.6481\end{array}$

